\title{
Association between Orthopedic and Dental Findings: What Level of Evidence is Available?
}

\section{Bein, Becken, Kopf, Wirbelsäule und zahnmedizinische Befunde - welches Evidenzniveau liegt vor?}

\author{
Birgit Amelie Hanke', Edith Motschall2 , Jens Christoph Türp ${ }^{3,4}$
}

\begin{abstract}
Objective: The aim of this systematic review was to provide comprehensive access to and an analysis of the specialist literature published through December 2005 describing a correlation between orthopedic (leg-length inequality, pelvis obliquity, column diseases and head posture) and dental findings (occlusion, mandibular position, temporomandibular joints, masticatory muscles). Method: Four medical and dental internet sources (PubMed; Medpilot.de; databases of the Deutsche Ärzte-Verlag and Quintessenz-Verlag) were screened for relevant articles using carefully selected retrieval strategies and keywords. Bibliographies of relevant articles were examined for further pertinent publications. All relevant articles were tabulated according to their year of publication, the subject area discussed, and the levels of scientific evidence.

Results: Our electronic inquiry yielded 359 relevant articles (electronic search: 195, search in bibliographies: 164), 355 of which could be analyzed. A correlation between dental findings and spinal column diseases was described in 266 articles, head posture in 216 , pelvis obliquity in 53 , and leg-length inequality in 35 papers. In 131 publications, conclusions were drawn from dental to orthopedic findings, whereas they were drawn from orthopedic to dental findings in 171 articles. The number of relevant articles rose significantly, particularly since the 1980 's. Classification in levels of evidence reveals three publications $(0.8 \%)$ with level II (randomized controlled trials), 63 (17.7\%) with level III (experimental studies with no randomization, cohort studies, or casecontrol studies), 178 (50.1\%) with level IV (non-experimental studies, such as cross-sectional trials, case series, case reports), and $111(31.3 \%)$ with level V (narrative review or expert opinion without explicit critical appraisal).
\end{abstract}

\footnotetext{
'Department of Prosthodontics, University Hospital Freiburg, Freiburg i.Br., Germany,

${ }^{2}$ Institute for Medical Biometry und Medical Informatics, University Hospital Freiburg, Freiburg i. Br., Germany,

${ }^{3}$ Clinic for Reconstructive Dentistry and Temporomandibular Disorders, Dental School, University of Basel, Basel, Switzerland,

${ }^{4}$ Interuniversity College for Health and Development, Seggau Castle, Austria.
}

Received: August 16, 2006; accepted: November 22, 2006

\section{Zusammenfassung}

Zielsetzung: Ziel dieses Beitrags war die Erstellung einer Übersicht und einer Analyse der bis Dezember 2005 publizierten Literatur zum Zusammenhang zwischen Beinlängendifferenz, Beckenschiefstand, Wirbelsäulenbefunden und/oder Kopfhaltung einerseits und zahnmedizinischen Befunden (0kklusion, Kieferfehlstellungen, Kiefergelenke, Kaumuskulatur) andererseits.

Methodik: Mit Hilfe von ausgewählten Suchstrategien erfolgten Recherchen in den elektronischen Informationsportalen PubMed und Medpilot.de und den Verlagsdatenbanken des Deutschen Ärzte-Verlags und des Quintessenz-Verlags. Die Literaturverzeichnisse aller relevanten Artikel wurden auf weitere Publikationen überprüft. Alle themenrelevanten Beiträge wurden hinsichtlich ihres Erscheinungsjahrs, thematischen Schwerpunkts und ihrer wissenschaftlichen Qualität ausgewertet.

Ergebnisse: Die Recherche ergab 359 relevante Artikel (elektronische Suche: 195, Suche in den Literaturverzeichnissen: 164), von denen 355 analysiert werden konnten. Ein Zusammenhang zahnmedizinischer Befunde mit Wirbelsäulenbefunden wurde in 266, mit Kopfhaltung in 216, mit Beckenschiefstand in 53 und mit Beinlängendifferenz in 35 Artikeln dargestellt. Rückschlüsse von einem zahnärztlichen auf einen orthopädischen Befund wurden in 131 Publikationen gezogen, in umgekehrter Richtung in 171 Artikeln. Vor allem seit den 1980er Jahren nimmt die Zahl relevanter Publikationen deutlich zu. Die Einstufung in Evidenzgrade ergab drei Artikel (0,8\%) mit Evidenzstufe II (randomisierte kontrollierte Studie), 63 (17,7\%) mit Evidenzgrad III (experimentelle Studie ohne Randomisierung, Kohortenstudie oder FallKontroll-Studie), $178(50,1 \%)$ mit Grad IV (nicht-experimentelle Studie, z.B. Querschnittstudie, Fallserie, Falldarstellung) und 111 $(31,3 \%)$ mit Grad V (traditioneller Übersichtsartikel oder Meinung angesehener Autoritäten ohne transparente Belege).

Schlussfolgerungen: (1) Die mangelnde Qualität der vorhandenen Publikationen über mögliche Zusammenhänge zwischen or-

\section{J Orofac Orthop 2007;68:91-107}

DOI 10.1007/s00056-007-0634-0

Electronic supplementary material is available in the online version of this article at http://dx.doi.org/10.1007/s00056-007-0634-0 and is accessible for authorized users. 
Conclusions: 1 ) While there is great interest in possible correlations between orthopedic and dental findings in the specialist literature, most publications fail to provide the hard facts and solid evidence characteristic of high-quality research. 2) This literature analysis attests to the importance of searching electronic databases while making the inherent weaknesses of such searches obvious. Manual literature searches remain essential.

Key Words: Leg-length inequality - Pelvic obliquity · Spinal signs or symptoms - Head posture - Manual searches - Evidence-based dentistry

Quantity is countable. Quality counts. Lothar Schmidt [281]

\section{Introduction}

Several publications in the German-language dental literature over the last few years have reported a functional relationship between orthopedic findings (spinal scoliosis, disturbances of the atlanto-occipital, atlanto-axial, and/or iliosacral joints, pelvis obliquity, leg-length inequality) and the masticatory system (occlusion, mandibular position, temporomandibular joints, masticatory muscles) [51, 260, 302, $303,330]$. The literature on this subject has originated in many countries (and languages) and is of variable quality, making assessment of the alleged associations difficult. We thus decided to carry out a systematic literature review. After compiling a list of relevant contributions published through December 2005, we analyzed their contents and quality.

\section{Methods}

Using specific retrieval strategies (see Appendix: electronic supplementary material at http://dx.doi. org/10.1007/s00056-007-0634-0), we used the following electronic information sources and databases:

- PubMed (www.pubmed.gov);

- Medpilot.de (www.medpilot.de);

- the database of the Deutscher Ärzte-Verlag (www.dzz. de) (considers the journals Deutsche Zahnärztliche Zeitschrift, Zeitschrift für Zahnärztliche Implantologie, Oralprophylaxe, and Zahnärztliche Mitteilungen);

- the database of the Quintessenz-Verlag (www. quintessenz.de) (considers the journals Die Quintessenz, Kieferorthopädie, Parodontologie, Implantologie, Endodontie, Quintessenz Team-Journal, and Quintessenz Zahntechnik).

The last electronic update was carried out on April 24, 2006. Furthermore, we combed through the references listed in the pertinent articles to identify additional relevant publi- thopädischen und zahnmedizinischen Befunden wird dem in der Fachliteratur zunehmend hohen Interesse an dieser Thematik nicht gerecht. (2) Bei einer alleinigen Suche in elektronischen Informationsportalen und Datenbanken müssen große inhaltliche Lücken in Kauf genommen werden; eine zusätzliche Handsuche ist daher unverzichtbar.

Schlüsselwörter: Beinlängendifferenz - Beckenschiefstand - Wirbelsäulenbefunde - Kopfhaltung - Handsuche $\cdot$ Evidenzbasierte Zahnmedizin

\section{Quantität lässt sich zählen. Qualität zählt. Lothar Schmidt [281] \\ Einleitung}

Seit einiger Zeit trifft man in der deutschsprachigen zahnärztlichen Literatur gehäuft auf Veröffentlichungen, in denen von einem funktionellen Zusammenhang zwischen orthopädischen Befunden (Skoliose der Wirbelsäule, Funktionsstörungen der Kopf- und Ileosakralgelenke, Beckenschiefstand, Beinlängendifferenzen) und dem Kauorgan (Okklusion, Unterkieferlage, Kiefergelenke, Kaumuskulatur u.a.) berichtet wird [51, 260, 302, 303, 330]. Bedauerlicherweise ist die Literatur $\mathrm{zu}$ dieser Thematik sehr verstreut und von unterschiedlicher Qualität, sodass eine Überprüfung der behaupteten Beziehungen schwierig ist. Aus diesem Grunde entschlossen wir uns, auf der Grundlage einer systematischen Literaturrecherche ein Verzeichnis der bis Dezember 2005 erschienenen Publikationen zum Zusammenhang zwischen orthopädischen und zahnmedizinischen Befunden zu erstellen und die gefundenen Beiträge einer inhaltlichen und qualitativen Analyse zu unterziehen.

\section{Methodik}

Mit Hilfe ausgewählter Suchstrategien (s. Anhang: electronic supplementary material unter http://dx.doi.org/ 10.1007/s00056-007-0634-0) erfolgten Recherchen in folgenden elektronischen Informationsportalen und Datenbanken: - PubMed (www.pubmed.gov),

- Medpilot.de (www.medpilot.de),

- Verlagsdatenbank des Deutschen Ärzte-Verlags (www. dzz.de, berücksichtigt die Zeitschriften Deutsche Zahnärztliche Zeitschrift, Zeitschrift für Zahnärztliche Implantologie, Oralprophylaxe und Zahnärztliche Mitteilungen), - Verlagsdatenbank des Quintessenz-Verlags (www. quintessenz.de, berücksichtigt die Zeitschriften Die Quintessenz, Kieferorthopädie, Parodontologie, Implantologie, Endodontie, Quintessenz Team-Journal und Quintessenz Zahntechnik). 
cations (e.g., journal articles, textbooks, book chapters, dissertations, course material). By doing so, our search encompassed the period from 1926 to December 2005. Except in PubMed (see Appendix, searches \#21 and \#22), there were no language restrictions. Each identified contribution was tabulated according to its year of publication and subject area. We documented how often relationships were postulated between dental findings (occlusion, jaw malalignment, temporomandibular joints, masticatory muscles) and orthopedic findings (column diseases, head posture, pelvis obliquity, leg-length inequality), and in which direction inferences were made (i.e., from dental to orthopedic findings, or vice versa).

The scientific quality of each contribution was evaluated using a modified version of the Antes classification [4] (Table 1). Referring to that author's definitions [4], we classified the publications as being a systematic review (level I), a randomized controlled trial (level II), a cohort study (level III), or case-control study (level III). Categorization as a non-experimental study (level IV: cross-sectional study, case series or case report) was made according to Khan et al. [156].

Moreover, we classified evidence level III as [156]:

- IIIa: experimental study without randomization

- IIIb: cohort study, or

- IIIc: case-control study.

To differentiate between publications classified in evidence level IV, we categorized according to:

- IVa: number of participants $>100$

- IVb: number of participants 20-100, or

- IVc: number of participants $<20$.

\section{Results}

The computer-assisted search in the four internet sources yielded 4,084 hits. After evaluation of the titles and, if available, the abstracts, 3,299 contributions were classified as irrelevant. Of the remaining 785 hits, 195 were relevant (590 were cumulative entries). After examining the bibliographies of those 195 contributions, 164 additional publications were identified, thus yielding a total of 359 relevant hits (Table 2).
Table 1. Hierarchy of strength of evidence for therapeutic decisions (modified according to [4]).

Tabelle 1. Hierarchie der wissenschaftlichen Evidenzstärke für TherapieEntscheidungen (modifiziert nach [4]).

\begin{tabular}{|c|c|}
\hline I & Systematic review of randomized controlled trials (RCTs) \\
\hline II & Article reporting an RCT \\
\hline III & $\begin{array}{l}\text { Article reporting an experimental study without randomization - } \\
\text { cohort study - case-control study }\end{array}$ \\
\hline IV & $\begin{array}{l}\text { Article reporting a non-experimental study (cross-sectional } \\
\text { study, case series, case report) }\end{array}$ \\
\hline & $\begin{array}{l}\text { Narrative review or expert opinion (based on clinical experience) } \\
\text { without explicit critical appraisal }\end{array}$ \\
\hline
\end{tabular}

Die letzte Aktualisierung der elektronischen Recherche erfolgte am 24.4.2006. Die Literaturverzeichnisse aller relevanten Beiträge wurden auf weitere themenbezogene Publikationen überprüft (Zeitschriftenbeiträge, Lehrbücher, Buchbeiträge, Dissertationen, Kursskripte etc.). Unsere Literatursuche umfasste so den Zeitraum von 1926 bis einschließlich Dezember 2005. Hinsichtlich der berücksichtigten Sprachen gab es außer in PubMed (s. Anhang, Suche \#21 und \#22) keine Einschränkungen. Alle identifizierten Beiträge wurden hinsichtlich Erscheinungsjahr und thematischem Schwerpunkt ausgewertet. Es wurde überprüft, wie häufig ein Zusammenhang zahnmedizinischer Befunde (bezüglich Okklusion, Kieferfehlstellungen, Kiefergelenken, Kaumuskeln) mit orthopädischen Befunden (Wirbelsäulenbefunden, Kopfhaltung, Beckenschiefstand und/oder Beinlängendifferenz) beschrieben wurde und wie oft Rückschlüsse von einem zahnärztlichen auf einen orthopädischen Befund sowie von einem orthopädischen auf einen zahnärztlichen Befund gezogen wurden.

Zudem wurde mit Hilfe einer modifizierten Einteilung nach Antes [4] jeder Beitrag nach seiner wissenschaftlichen Qualität beurteilt (Tabelle 1). Die Einordnung als systematische Übersicht (Stufe I), randomisierte kontrollierte Studie (Stufe II), Kohortenstudie (Stufe III) und Fall-Kontroll-Studie (Stufe III) erfolgte dabei auf der Grundlage der Definitionen von Antes [4], die Bewertung als nicht-experimentelle Studie (Stufe IV: Querschnittstudie, Fallserie oder

Table 2. Distribution of the results after searching in the four internet resources and reference lists of the relevant articles.

Tabelle 2. Trefferverteilung in den vier Informationsquellen und bei der Suche in den Literaturverzeichnissen der relevanten Artikel.

\begin{tabular}{|c|c|c|c|c|c|}
\hline \multirow{2}{*}{$\begin{array}{l}\text { Hits from } \\
\text { electronic search }\end{array}$} & \multicolumn{4}{|c|}{ Internet resource } & \multirow[t]{2}{*}{ Search in the references } \\
\hline & PubMed & Medpilot & DÄV & Quintessenz & \\
\hline Total & 2139 & 1745 & 117 & 83 & \\
\hline Relevant & 503 & 259 & 22 & 1 & \\
\hline Total relevant & \multicolumn{4}{|c|}{785} & \\
\hline ... without cumulative hits & \multicolumn{4}{|c|}{195} & 164 \\
\hline Overall relevant & \multicolumn{4}{|c|}{359} & \\
\hline
\end{tabular}




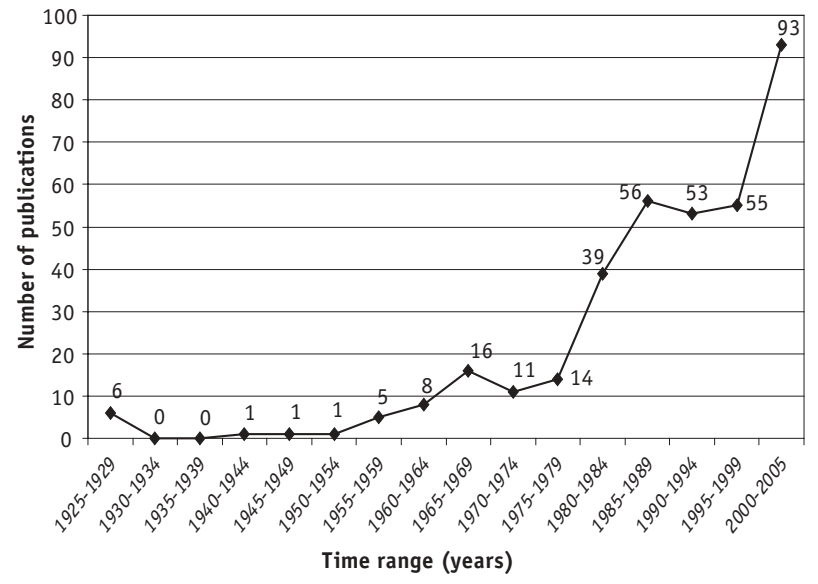

Figure 1. Development of the total number of identified publications from 1926 to 2005.

Abbildung 1. Entwicklung der Gesamtzahl der identifizierten Publikationen zwischen 1926 und 2005.

Of those, four articles without an English-language abstract could not be assessed; one contribution was in Russian [167], while full texts of the remaining three articles [277, 278,376 ] could not be obtained from the German National Library of Medicine (Cologne, Germany) or the University Library in Freiburg im Breisgau (Germany). Thus 355 publications were available for our analysis.

A relationship was described between the masticatory system and spinal column in 266 publications, an association with head posture in 216 articles, pelvis obliquity in 53 papers, and leg-length inequality in 35 publications. Inferences from dental to orthopedic findings were made in 131 publications, whereas associations in the opposite direction were drawn in 171 contributions.

We noted a particular increase in the number of publications since the 1980's (Figure 1). This is mainly due to articles focussing on the spine and/or on head position: For example, 69 publications between 2000 and 2005 were identified postulating an association between the masticatory system and spinal column (head position: 63 publications). In contrast, special interest in pelvis obliquity and leg-length inequality has only become obvious in the past 10 years, as revealed by a sharp rise in contributions concerning topics published since 1995; 23 articles on pelvis obliquity and 19 on leg-length inequality were published between 2000 and 2005.

No systematic review of randomized controlled trials (RCTs) was published during the period covered by our search. Three contributions $(0.8 \%)$ were articles about RCTs (evidence level II). Two of those papers evaluated the therapeutic benefit of postural exercises for the management of patients with myofascial pain of the masticatory muscles [166, 360], while the third reported on the consequences of rapid maxillary expansion on head posture (among others) [319].
Fallbericht) gemäß den Angaben von Khan et al. [156]. Zusätzlich wurde nach Khan et al. [156] der Evidenzgrad III wie folgt unterteilt:

- IIIa: experimentelle Studie ohne Randomisierung,

- IIIb: Kohortenstudie oder

- IIIc: Fall-Kontroll-Studie.

Um einen in den Evidenzgrad IV eingestuften Beitrag quantitativ differenzieren zu können, unterteilten wir in:

- IVa: Probandenzahl > 100,

- IVb: Probandenzahl 20-100,

- IVc: Probandenzahl $<20$.

\section{Ergebnisse}

Die computerunterstützte Recherche in den vier Informationsquellen ergab eine Gesamttrefferzahl von 4084 Beiträgen. Davon wurden nach Prüfung des Titels und, falls vorhanden, der Kurzzusammenfassungen (Abstracts) 3299 Beiträge als irrelevant eingestuft. Von den verbleibenden 785 Treffern blieben nach Abzug von 590 kumulativen Nennungen 195 relevante Treffer übrig. Weitere 164 Publikationen wurden durch Überprüfen der Literaturverzeichnisse dieser 195 Beiträge ausfindig gemacht, sodass insgesamt 359 Beiträge gefunden wurden (Tabelle 2).

Von diesen konnten vier Artikel - alle ohne englischsprachigen Abstract - nicht bewertet werden: Ein Beitrag lag zwar als Volltext vor, war aber auf Russisch verfasst [167], während die restlichen drei Artikel [277, 278, 376] weder von der Deutschen Zentralbibliothek der Medizin in Köln noch von der Universitätsbibliothek Freiburg im Volltext beschafft werden konnten. Daher standen für unsere Analyse 355 Publikationen zur Verfügung.

Ein Zusammenhang zahnmedizinischer Befunde mit Wirbelsäulenbefunden wurde in 266, mit Kopfhaltung in 216, mit Beckenschiefstand in 53 und mit Beinlängendifferenz in 35 Artikeln beschrieben. Rückschlüsse von einem zahnärztlichen auf einen orthopädischen Befund wurden in 131 , von einem orthopädischen auf einen zahnärztlichen Befund in 171 Publikationen gezogen.

Die Zahl der Publikationen hat vor allem seit den 1980er Jahren stark zugenommen (Abbildung 1). Dies betrifft insbesondere Artikel, die sich mit Wirbelsäule und/oder Kopfhaltung beschäftigen; für den Zeitraum 2000-2005 beispielsweise wurden 69 Beiträge in Zusammenhang mit der Wirbelsäule und 63 mit der Kopfposition identifiziert. Beckenschiefstand und Beinlängendifferenz fanden demgegenüber erst in den vergangenen 10 Jahren vermehrtes Interesse, was durch einen steilen Anstieg der ab 1995 erschienenen Veröffentlichungen zum Ausdruck kommt; zwischen 2000 und 2005 wurden 23 (Beckenschiefstand) bzw. 19 (Beinlängendifferenz) Beiträge publiziert.

Eine systematische Übersicht randomisierter kontrollierter Studien war in dem Untersuchungszeitraum nicht veröffentlicht worden. Drei Beiträge $(0,8 \%)$ waren Artikel über 
Osamu Komiyama et al. (Chiba, Japan) [166] included 60 patients with myofascial pain and limited jaw opening in a 1-year trial [74]. The study participants were randomized into one of three groups: Patients in group 1 received cognitive behavioral therapy every month according to the method of Dworkin et al. [75] (patient information; training in pain- and stress-coping strategies such as progressive relaxation), group 2 received monthly cognitive behavioral therapy plus instructions in posture correction during sitting, standing, sleeping, eating, walking, and carrying heavy loads, and group 3 (controls) received every month general instructions emphasizing optimum jaw function as described by Burgess et al. [25]. The trial results do suggest that posture correction in addition to cognitive behavioral therapy, as compared to cognitive behavioral interventions alone, may increase the therapeutic benefit at least in part. For instance, maximum unassisted pain-free jaw opening in group 2 was significantly greater as early as 1 month after therapy (in group 1 it was after 2 months, and after 6 months in group 3 ). In addition, group 2 - as compared to group 1 - showed a greater reduction in interferences in daily life and lower pain intensity during maximum jaw opening, each measured with a $100 \mathrm{~mm}$ visual analog scale; however, the differences observed did not reach statistical significance.

Edward Wright and his team at Lackland Air Force Base in Texas, USA [360] randomized 60 patients with at least moderate jaw muscle pain into one of two groups: One therapy group received posture training administered by a physical therapist, while the other served as a control group. Before the study started, patients in both groups were given information about jaw function and instructions for the selfmanagement of temporomandibular disorders (TMDs) (application of heat and cold, use of over-the-counter anti-inflammatory medications, improving head and neck posture) [361]. Four weeks after the trial's start, significant improvement was observed in the therapeutic group with regard to pain reduction, maximum unassisted pain-free jaw opening, pressure-algometer pain threshold of the masseter and trapezius muscles, and symptoms perceived by the patients.

Simona Tecco et al. [319] included 55 girls (mean age: 8 years) with reduced nasopharyngeal airway adequacy and mouth breathing. They had been admitted to the Department of Orthodontics and Gnathology, University of Chieti (Italy), for maxillary expansion. The girls were randomized into a study group or control group. (The control-group treatment began about 8 months later than that of the study group.) For the maxillary expansion, 4 turns ( 1 turn $=0.2 \mathrm{~mm}$ ) were made on the appliance $\left(\mathrm{REP}^{\circledR}\right.$; Dentaurum Italia) the first day, followed by 2 turns per day until the desired result was achieved. The appliance remained in place thereafter for an average of nearly 5 months. Six months after the start of expansion, a significant backward inclinication of the upper cervical column and significant flexion of the head were observed in the study group (as compared to baseline and the control group). randomisierte, kontrollierte Studien (Evidenzstufe II). In zwei Fällen betreffen diese Beiträge den therapeutischen Nutzen von Haltungsübungen im Rahmen der Behandlung von Patienten mit myofaszialen Schmerzen der Kiefermuskeln $[166,360]$, in einem Fall die Auswirkung einer raschen Oberkiefer-Expansion auf (unter anderem) die Kopfhaltung [319].

Osamu Komiyama et al. (Chiba, Japan) [166] schlossen in ihre 1-Jahres-Studie 60 Patienten mit myofaszialen Kaumuskelschmerzen und eingeschränkter Kieferöffnung [74] ein. Die Studienteilnehmer wurden in eine von drei Gruppen randomisiert: In Gruppe 1 wurde jeden Monat eine kognitive Verhaltenstherapie gemäß den Anleitungen von Dworkin et al. [75] durchgeführt (Aufklärung; Einführung in schmerzund stressabwehrende Strategien wie progressive Muskelrelaxation). Gruppe 2 erhielt monatlich eine kognitive Verhaltenstherapie plus Anleitungen zur Haltungskorrektur beim Sitzen, Stehen, Schlafen, Essen, Gehen, Lastenheben. Gruppe 3 (Kontrolle) erhielt, wie von Burgess et al. [25] beschrieben, jeden Monat allgemeine Hinweise zur optimalen Kieferfunktion. Die Ergebnisse der Studie lassen den Schluss zu, dass eine zusätzliche Haltungskorrektur den Nutzen gegenüber einer ausschließlichen kognitiven Verhaltenstherapie zumindest teilweise erhöhen kann. So war in Gruppe 2 die maximale aktive schmerzfreie Kieferöffnung bereits nach 1 Monat signifikant größer als vor Therapiebeginn (Gruppe 1: nach 2 Monaten; Gruppe 3: nach 6 Monaten). Bezüglich des Rückgangs der Einschränkungen im täglichen Leben sowie der Schmerzintensität bei maximaler Kieferöffnung, jeweils gemessen mit einer 100 mm langen visuellen Analogskala, wies Gruppe 2 gegenüber Gruppe 1 zwar konstant günstigere Werte auf, die beobachteten Unterschiede erreichten allerdings keine statistische Signifikanz.

Edward Wright und Kollegen (Lackland Air Force Base, Texas, USA) [360] randomisierten 60 Patienten mit mindestens mittelstarken Kaumuskelschmerzen in eine von zwei Gruppen: Die Therapiegruppe erhielt Haltungstraining durch einen Physiotherapeuten, die andere Gruppe diente als Kontrolle. Vor Beginn der Studie hatten beide Gruppen bereits eine Aufklärung zum Thema „Kieferfunktion“ sowie Anleitungen zur Selbstbehandlung erhalten (Anwendung von Wärme oder Kälteanwendung sowie nicht-steroidaler Antiphlogistika, Hinweise zur Verbesserung der Haltung) [361]. Im Vergleich zum Ausgangszustand zeigten sich in der Therapiegruppe 4 Wochen nach Studienbeginn signifikante Besserungen hinsichtlich Schmerzreduktion, maximaler aktiver schmerzfreier Kieferöffnung, Druckempfindlichkeit am Musculus masseter und am Musculus trapezius und der empfundenen Symptomatik.

Die Arbeitsgruppe um Simona Tecco [319] untersuchte 55 Mädchen(Altersdurchschnitt:8 Jahre) mit eingeschränkter nasopharyngealer Atemwegsfunktion und Mundatmung. Die Patientinnen hatten sich zum Zwecke einer OberkieferExpansion in der Abteilung für Kieferorthopädie und Gnathologie der Universität Chieti (Italien) eingefunden. Die 
Table 3. Classification of the articles according to their levels of evidence.

Tabelle 3. Einteilung der identifizierten Beiträge gemäß Evidenzniveau.

\begin{tabular}{|c|c|c|}
\hline Evidence level & Number & Literature \\
\hline I & 0 & \\
\hline II & 3 & {$[166,319,360]$} \\
\hline III a & 8 & {$[6,58,145,184,212,216,248,359]$} \\
\hline III $b$ & 9 & {$[2,3,15,16,97,108,137,159,363]$} \\
\hline III c & 46 & $\begin{array}{l}{[13,22,40,53,57,62,63,70,83-85,94,95,99,111,112,115,116,128,138,140,142-144,165,183,204,229,230,} \\
233,242,244,251,256-259,276,289,306,307,339,341,350,372,378]\end{array}$ \\
\hline IV a & 27 & $\begin{array}{l}{[18,42,56,68,69,90,103,120,122,127,129,130,139,197,198,207,210,227,228,235,247,255,262,274,297,} \\
317,377]\end{array}$ \\
\hline IV b & 61 & $\begin{array}{l}{[19,20,23,24,28,33,37,45,81,82,86,88,89,96,102,105,106,113,124,125,148,154,155,163,174,175,179,} \\
187-189,192,202,205,221,226,234,236,240,253,261,269,279,280,287,293-295,298,299,301,305,322,325, \\
335,337,343,346,349,353,354,374]\end{array}$ \\
\hline IV c & 90 & $\begin{array}{l}{[5,14,21,31,39,41,52,59,76,78-80,87,98,107,114,117,118,121,133-136,146,147,153,157,158,160-162,} \\
164,168,194-196,199,203,208,209,213,215,217,222-225,231,241,243,245,254,270-273,275,285,290,300, \\
308,309,313,315,316,318,320,324,329,332-334,338,340,347,348,356,357,362,364-371,373,375,379]\end{array}$ \\
\hline V & 111 & $\begin{array}{l}{[1,9-12,17,26,27,29,30,32,35,36,38,43,44,46-50,54,55,60,61,64-67,71-73,77,91-93,100,101,104,109,} \\
110,119,123,126,131,132,141,149-152,169-173,176-178,181,182,185,186,190,191,193,200,201,206,211, \\
214,218-220,232,237,238,246,249,250,252,263-268,282-284,286,288,291,292,296,304,310,312,314,321, \\
323,328,331,336,342,344,345,351,352,355,358]\end{array}$ \\
\hline
\end{tabular}

However, the authors maintain that it is highly uncertain whether these changes are clinically relevant.

Sixty-three contributions $(17.7 \%)$ were identified having evidence level III, 178 (50.1\%) with level IV, and 111 $(31.3 \%)$ with level V (Table 3, Figure 2).

\section{Discussion}

An analysis of the identified literature shows that the number of published articles has risen markedly since the 1980's, with a major jump between 2000 and 2005 (Figure

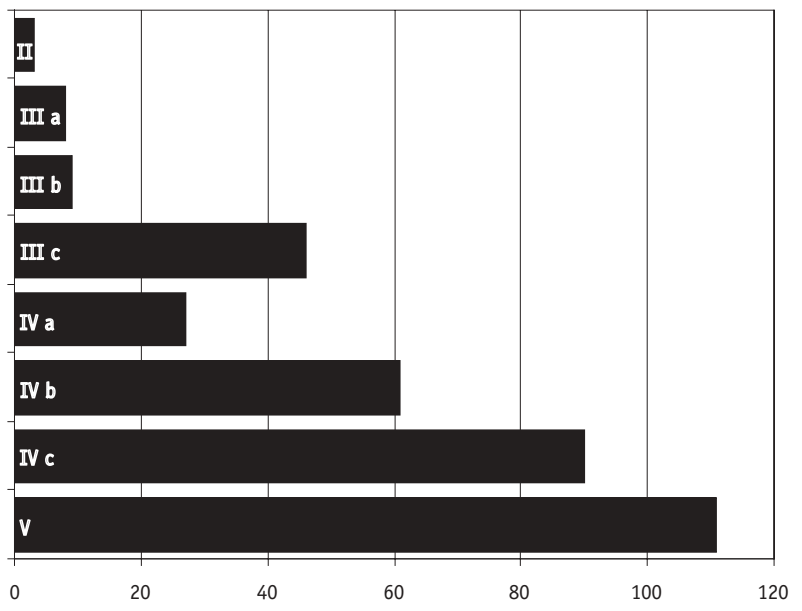

Figure 2. Distribution of the identified publications according to their levels of evidence.

Abbildung 2. Verteilung der identifizierten Publikationen nach ihrem Evidenzniveau.
Mädchen wurden zufällig in eine Studiengruppe oder eine Kontrollgruppe eingeteilt. (Die Behandlung der Kontrollgruppe begann rund 8 Monate später als die der Studiengruppe.) Für die Expansion wurden am Expansionsgerät (REP ${ }^{\circledR}$; Dentaurum Italia) am ersten Tag vier Umdrehungen getätigt (1 Umdrehung $=0,2 \mathrm{~mm}$ ), an den Folgetagen jeweils zwei Umdrehungen, bis das gewünschte Ergebnis vorlag. Anschließend blieb das Gerät durchschnittlich knapp 5 Monate in situ. In der Studiengruppe waren 6 Monate nach Behandlungsbeginn (im Vergleich zum Befund vor der Therapie sowie zur Kontrollgruppe) unter anderem eine statistisch signifikante Rückwärtsinklination der oberen Halswirbelsäule und eine signifikante Flexion des Kopfes vorhanden. Allerdings stellen die Autoren fest, dass es sehr unsicher sei, ob die beobachteten Veränderungen klinisch relevant sind.

Die weitere Einstufung in Evidenzgrade ergab 63 Beiträge $(17,7 \%)$ mit Evidenzgrad III, 178 Publikationen (50,1\%) mit Grad IV und 111 Artikel (31,3\%) mit Grad V (Tabelle 3, Abbildung 2).

\section{Diskussion}

Wenn man die zeitliche Entwicklung der Publikationen zum Zusammenhang zwischen orthopädischen und zahnmedizinischen Befunden analysiert, so erkennt man, dass die Zahl der veröffentlichten Artikel seit den 1980er Jahren stark zugenommen hat und im Zeitraum 2000-2005 nochmals sprunghaft gestiegen ist (Abbildung 1). Einige der in letzter Zeit erschienenen Publikationen widmeten sich hochspeziellen Fragestellungen, ohne dass dabei auf eine ebenso hohe methodische Qualität geachtet wurde. So beschäftigten sich beispielsweise Valentino et al. [334] mit 
1). Several papers published recently address highly specialized topics, while their methodology reveal serious shortcomings. For example, Valentino et al. [334] report on the relationship between the plantar arches of the foot and dental occlusion, yet their article has an evidence level of only IVc.

Generally speaking, there is an obvious discrepancy between quality and quantity in this literature. The fact that $99.2 \%$ of all contributions have an evidence level of III, IV or $\mathrm{V}$ (Figure 2) should serve as a warning to clinicians not to give the results of these papers too much credit, especially in light of the ever-growing influence of evidence-based medicine (EBM) in German-speaking countries and elsewhere. EBM traditionally rests on three pillars requiring consideration when making clinical decisions [311,326]:

- external evidence, i.e., results from valid and clinicallyrelevant research, particularly from patient-centered clinical research,

- internal evidence, i.e., the dentist's and/or physician's clinical expertise, and

- the patient's values and preferences.

(A fourth pillar has recently been added, namely the patient's circumstances, that is, his or her clinical status, and the clinical setting [311]).

If the quality of the best available evidence is low, as was the case in this analysis, the results are apt to be misinterpreted, and there is a latent danger of over-diagnosis and over-treatment. The results of our review suggest that statements made with great self-confidence by some authors (and treatment providers) regarding a purported relationship between orthopedic and dental findings are not based on solid scientific grounds. A Chilean-Canadian group came to the same conclusion recently [7a]: in a systematic review assessing the association between head and cervical posture and TMDs Armijo Olivo et al. identified twelve relevant articles. With the exception of two publications not listed in PubMed $[8,34]$, their articles are also included in our analysis [22, 53, $57,115,145,179,183,233,299,339]$. They criticized the studies' poor methodology and concluded that it remains unclear whether head and cervical posture are related to TMD symptoms. In a subsequent critical review, Armijo Olivo et al. [7b] mention a tendency towards a connection between the cervical spine, the stomatognathic system and craniofacial pain; however, due to the studies' limitations, they advise clinicians to take care when interpreting the results.

Apart from the objections specifically related to the study design, our analysis reveals that a search limited to electronic information sources and databases is likely to lead to incomplete results: It is possible that not all relevant articles can be found with our search strategies. In addition, the electronic sources themselves do not cover all medical and dental journals. Medline, for instance, covers roughly $40 \%$ of all dental titles [239]. Thus it is not surprising that PubMed misses almost half of all articles reporting dental RCTs in dem Einfluss der Fußwölbung auf die Okklusion; ihre Studie weist allerdings den niedrigen Evidenzgrad IVc auf.

Allgemein herrscht eine auffällige Diskrepanz zwischen Quantität und Qualität vor. Die Erkenntnis, dass 99,2\% aller im Berichtszeitraum erschienenen Artikel keine hohe Evidenzstufe aufweisen (Stufe III, IV oder V; Abbildung 2), sollte jeden Kliniker zur Vorsicht bei der Interpretation der Studienergebnisse mahnen, nicht zuletzt im Hinblick auf die auch im deutschsprachigen Raum allmählich Fuß fassende evidenzbasierte Medizin (EbM). Traditionsgemäß steht die EbM auf drei Pfeilern, die für patientenbezogene Entscheidungen zu berücksichtigen sind [311, 326]:

- Externe Evidenz, d.h. valide und klinisch relevante Forschungsergebnisse, vor allem aus patientenzentrierter klinischer Forschung,

- interne Evidenz, d.h. der klinische Sachverstand des (Zahn-)Arztes,

- die Wertvorstellungen und Präferenz des Patienten.

(Jüngst wurde ein vierter Pfeiler hinzugefügt: der Zustand des Patienten und das klinische Umfeld [311]).

Wenn aber, wie für den von uns untersuchten Bereich, die beste verfügbare wissenschaftliche Evidenz von schwacher Qualität und daher stark anfällig gegenüber Fehlinterpretationen ist, dann besteht die latente Gefahr einer Patientengefährdung durch Überdiagnostik und Übertherapie. Die von einigen Autoren (und Behandlern) mit großem Selbstbewusstsein geäußerten Thesen zum angeblichen $\mathrm{Zu}$ sammenhang zwischen orthopädischen und zahnmedizinischen Befunden stehen jedenfalls auf keiner soliden wissenschaftlichen Grundlage. Zu demselben Schluss kam vor Kurzem die chilenisch-kanadische Arbeitsgruppe um Armijo Olivo [7a]: In einer im Jahr 2006 veröffentlichten systematischen Übersicht zum Zusammenhang zwischen Kopf- und Halshaltung einerseits und Kiefergelenk- und Kaumuskelbeschwerden andererseits identifizierten die Autoren zwölf relevante Artikel; bis auf zwei nicht in PubMed gelistete Beiträge $[8,34]$ sind diese auch in unserer Analyse enthalten [22, 53, 57, 115, 145, 179, 183, 233, 299, 339]. Die Autoren monierten die schwache methodische Qualität der Studien und kamen zu der Schlussfolgerung, dass es unklar sei, ob Kopfund Halshaltung mit myoarthropathischen Beschwerden einhergehen. In einer wenig später veröffentlichten kritischen Übersicht berichteten Armijo Olivo et al. [7b] zwar von einem tendenziell bestehenden Zusammenhang zwischen der Halswirbelsäule, dem stomatognathen System und kraniofazialen Schmerzen; angesichts der Qualitätseinschränkungen der vorhandenen Literatur raten sie aber zur Vorsicht bei der Interpretation der Studienergebnisse.

Unabhängig von diesen studienbezogenen Gesichtspunkten zeigt unsere Recherche, dass eine alleinige Suche in elektronischen Informationsportalen und Literaturdatenbanken zur Erlangung eines möglichst vollständigen Ergebnisses nicht ausreicht: Möglicherweise werden mit der Suchstrategie nicht alle relevanten Artikel in der jeweiligen Datenbank gefunden. 
German [327]. We found $45.7 \%$ of all relevant publications by searching in the reference lists of papers identified electronically. It is very likely that a focussed manual search in selected journals would have increased the number of relevant contributions we identified.

There are two reasons for the paucity of pertinent contributions from the first half of the last century. First, the topic in question did not attract as much interest as it does nowadays, second, publications published in 1950 or earlier were only found by their having been cited in previouslyidentified relevant contributions. Since OldMedline, which is part of PubMed, only covers the period from 1951 to 1965 , a comprehensive manual search in selected journals and textbooks is necessary if one aims to make valid statements about the quantity and quality of relevant contributions published then. Such an interesting and important task remains to be done.

\section{Conclusions}

1. There is growing interest in possible correlations between orthopedic and dental findings, yet there is a lack of methodologically sound clinical studies [7] whose results might shed light on a field dominated by hypotheses and theories. Due to the poor quality of most publications, the factual base is small.

2. A literature search limited to electronic information sources and databases usually leads to incomplete results, which is why manual searches are usually imperative. Moreover, we recommend a systematic search of the reference lists of identified publications.

3. In the closing words of his "Theory of Colors", published in 1810, Johann Wolfgang von Goethe remarked that each new discovery and treatment approach, even errors may be useful or exciting, and that they are not lost for the future. This should encourage researchers to carry out methodologically sound clinical trials that may solve some of the unanswered questions posed in this article.

\section{References}

1. Ahlers 0. Funktionsdiagnostik - Systematik und Auswertung. Zahnärztl Mitt 2004;94:2934-43.

2. Alanen P, Kirveskari P. Occupational cervicobrachial disorder and temporomandibular joint dysfunction. J Craniomandib Pract 1984;3:69-72.

3. Alexander RG. The effects on tooth position and maxillofacial vertical growth during treatment of scoliosis with the Milwaukee brace. Am J Orthod 1966;52:161-89.

4. Antes G. Evidence-based medicine. Internist 1998;39:899-908.

5. Araki NG, Araki CT. Head angulation and variations in the maxillomandibular relationship. Part I: The effects on the vertical dimension of occlusion. J Prosth Dent 1987;58:96-100.

6. Archer SY, Vig PS. Effects of head position on intraoral pressures in Class I and in Class II adults. Am J Orthod 1985;87:311-8.
Außerdem sind die elektronischen Quellen unvollständig: Es gibt mehr Fachzeitschriften, als von den Betreibern dieser elektronischen Quellen berücksichtigt werden. So deckt beispielsweise die Literaturdatenbank Medline nur knapp 40\% aller aktiven Titel der Zahnmedizin ab [239]. Aus diesem Grund verwundert es kaum, dass fast die Hälfte der in deutscher Sprache veröffentlichten zahnmedizinischen Artikel über randomisierte klinische Studien nicht in PubMed gelistet sind [327]. In unserem Fall trugen die durch die Literaturverzeichnis-Suche identifizierten zusätzlichen Artikel zu 45,7\% zur Gesamtzahl aller identifizierten relevanten Publikationen bei. Es ist sehr wahrscheinlich, dass eine gezielte Handsuche in ausgewählten Fachzeitschriften die Trefferquote weiter erhöht hätte.

Die Tatsache, dass die Zahl der gefundenen Beiträge, die aus der ersten Hälfte des vergangenen Jahrhunderts stammen, sehr gering ist, liegt nicht nur an der damals viel selteneren Beschäftigung mit der von uns untersuchten Thematik, sondern ist auch dadurch begründet, dass wir auf solch frühe Veröffentlichungen lediglich durch Zitierungen in den Literaturverzeichnissen der bereits identifizierten Beiträge gestoßen sind. Da zudem die in PubMed integrierte Datenbank OldMedline nur den Zeitraum von (derzeit) 1951 bis 1965 abdeckt, ist eine umfassende Handsuche in ausgewählten Fachzeitschriften und Lehrbüchern notwendig, um genaue Aussagen über die Quantität und Qualität der in dieser Jahrhunderthälfte veröffentlichten Artikel zu machen. Eine solche, durchaus interessante und nicht unwichtige Aufgabe bleibt einer künftigen Arbeit vorbehalten.

\section{Schlussfolgerungen}

1. Fragen zu möglichen Zusammenhängen zwischen orthopädischen und zahnmedizinischen Befunden wecken zunehmend das Interesse der Fachliteratur. Doch fehlen klinische Studien hoher methodischer Qualität [7], die Licht in das von Hypothesen und Theorien dominierte Feld bringen. Aufgrund der eingeschränkten Qualität der vorhandenen Publikationen ist das gesicherte Wissen äußerst beschränkt.

2. Bei einer Literatursuche, die auf elektronische Informationsportale und Datenbanken beschränkt bleibt, müssen in der Regel große inhaltliche Lücken in Kauf genommen werden; eine zusätzliche Handsuche ist daher in den meisten Fällen unverzichtbar. Als unerlässlich hat sich die systematische Suche in den Literaturverzeichnissen bereits gefundener Artikel erwiesen.

3. Johann Wolfgang von Goethes Bemerkung (im Schlusswort seines 1810 erschienenen Werks „Zur Farbenlehre“), wonach ,jedes neue Verhältnis, das an den Tag kommt, jede neue Behandlungsart, selbst das Unzulängliche, selbst der Irrtum brauchbar oder aufregend und für die Folge nicht verloren“ ist, sollte Anstoß für die Durchführung hochwertiger wissenschaftlicher Untersuchungen sein, die zu einer Klärung einiger der in diesem Beitrag aufgeworfenen Fragen beitragen können. 
7a. Armijo Olivo S, Bravo J, Magee DJ, Thie NMR, Major PW, Flores-Mir C. The association between head and cervical posture and temporomandibular disorders: a systematic review. J Orofac Pain 2006;20:9-23.

7b. Armijo Olivo S, Magee DJ, Parfitt M, Major P, Thie NMR. The association between the cervical spine, the stomatognathic system, and craniofacial pain: a critical review. J Orofac Pain 2006;20:271-87.

8. Armijo-Olivo S, Frugone R, Wahl F, Gaete J. Alteraciones teleradiográficas craneocervicomandibulares en pacientes con desplazamiento anterior de disco con reducción. Kinesiologia 2001;64: 82-7.

9. Ayub E, Glasheen-Wray M, Kraus S. Head posture: a case study of the effects on the rest position of the mandible. J Orthop Sports Phys Ther 1984;5:179-83.

10. Bahnemann F. Kieferorthopädie als Funktionstherapie bei jugendlichen Haltungsschäden. Schlesw Holst Ärztebl 1969;22:174-84.

11. Bahnemann F. Über Para- und Dysfunktionen beim Gnatho-Vertebral-Syndrom und die Möglichkeiten ihrer Therapie. Zahnärztl Mitt 1973;20:1005-10.

12. Balters W. Die Wirbelsäule aus der Sicht des Zahnarztes. Zahnärztl Mitt 1964;9:408-12.

13. Bazzotti L. Mandible position and head posture: Electromyography of sternocleidomastoids. J Craniomandib Pract 1998;16:100-8.

14. Benech A, Fasciolo A, De Gioanni PP, Madaro E. Valutazione della postura in soggetti disgnatici prima e dopo intervento ortochirugico. Minerva Stomatol 1997;46:435-41.

15. Bergbreiter C: Untersuchungen über die Zusammenhänge zwischen Fehlstatik und den funktionellen Befunden des craniomandibulären Systems. Inaug.-Diss., Med. Fak. Tübingen, 1993.

16. Bernhöft K, Klammt J. Untersuchungen über Beziehungen zwischen funktionellen Störungen an den Kiefergelenken und der Halswirbelsäule. Zahn Mund Kieferheilkd 1988;76:36-9.

17. Bernstein I, Bernstein P, Salibello M. Improving oral functioning in a congenital spinal atrophy patient by occlusal rehabilitation. NY State Dent J 1987;53:24-6.

18. Blood SD, Virginia A. The craniosacral mechanism and the temporomandibular joint. J Am 0steopath Assoc 1986;86:512-9.

19. Boyd CH, Slagle WF, Boyd CM, Bryant RW, Wiygul JP. The effect of head position on electromyographic evaluations of representative mandibular positioning muscle groups. J Craniomandib Pract 1987:5:50-4.

20. Bracco P, Deregibus A, Piscetta R. Effects of different jaw relations on postural stability in human subjects. Neurosci Lett 2004;19:22830.

21. Bracco P, Deregibus A, Piscetta R, Ferrario G. Observations on the correlation between posture and jaw position: a pilot study. $\mathrm{J}$ Craniomandib Pract 1998;16:252-8.

22. Braun BL. Postural differences between asymptomatic men and women and craniofacial pain patients. Arch Phys Med Rehabil 1991;72:653-6.

23. Brenman HS, Amsterdam M. Postural effects on occlusion. Dent Progr 1963;4:43-7.

24. Bunch WB. Orthodontic positioner treatment during orthopedic treatment of scoliosis. Am J Orthod 1961;47:174-204.

25. Burgess JA, Sommers EE, Truelove EL, Dworkin SF. Short-term effect of two therapeutic methods on myofascial pain and dysfunction of the masticatory system. J Prosthet Dent 1988;60:606-10.

26. Caltabiano M, Verzi P, Scire SG. Considerazioni sulla postura del capo in ortognatodonzia: fisiologica della postura del capo Nota I. Mondo Ortod 1986;11:41-62.

27. Caltabiano M, Verzi P, Scire SG. Considerazioni sulla postura del capo in ortognatodonzia: fisiopatologia ed aspetti clinici Nota II. Mondo Ortod 1989;14:313-24.

28. Carossa S, Catapano S, Previgliano V, Preti G. Incidenza dei disordini cranio-mandibolari in pazienti con disfunzioni cervicali. Una valutazione clinico-statistica. Minerva Stomatol 1993;42:229-33.
29. Catanzariti J-F, Debuse T, Duquesnoy B. Chronic neck pain and masticatory dysfunction. Joint Bone Spine 2005;72:515-9.

30. Chadenat A. Modifications des structures faciales maxillaires et dentaires consécutives au traitement des scolioses par le corset de Milwaukee. Orthod Fr 1974;45:543-51.

31. Chapman RJ, Maness WL, Osorio J. Occlusal contact variation with changes in head position. Int J Prosthodont 1991;4:377-81.

32. Chek P, Curl DD. Posture and craniofacial pain. In: Curl DD, ed. Chiropractic Approach to Head Pain. Baltimore: Williams \& Wilkins, 1994:121-62.

33. Chessa G, Capobianco S, Lai V. Stabilometria e disturbi cranio-cervico-mandibolari. Minerva Stomatol 2002;51:167-71.

34. Chiao L, Guedes Z, Vieira M. Relação da postura corporal com a disfunção da articulação temporomandibular: hiperatividade dos músculos da mastigação. Fisioterapia Brasil 2003;4:341-7.

35. Chinappi ASJ, Getzoff H. The dental-chiropractic co-treatment of structural disorders of the jaw and temporomandibular joint dysfunction. J Manip Physiol Ther 1995;18:476-81.

36. Chinappi ASJ, Getzoff H. Chiropractic/dental cotreatment of lumbosacral pain with temporomandibular joint involvement. J Manip Physiol Ther 1996;19:607-12.

37. Choi B, Baek S-H, Yang W-S, Kim S. Assessment of the relationships among posture, maxillomandibular denture complex, and soft-tissue profile of aestetic adult Korean woman. J Craniofac Surg 2000;11:586-94.

38. Clark GT. Examining temporomandibular disorder patients for cranio-cervical dysfunction. J Craniomandib Pract 1983;2:55-63.

39. Clark GT, Browne PA, Nakano M, Yang Q. Co-activation of sternocleidomastoid muscle during maximum clenching. J Dent Res 1993;72:1499-502.

40. Clark GT, Green EM, Dornan MR, Flack VF. Craniocervical dysfunction levels in a patient sample from a temporomandibular joint clinic. J Am Dent Assoc 1987;115:251-6.

41. Cohen S. A cephalometric study of rest position in edentulous persons: influence of variations in head position. $J$ Prosth Dent 1957;7:467-72.

42. Cole SC, Orth D. Natural head position, posture, and prognathism: the Chapman Prize Essay, 1986. Br J Orthod 1988;15:227-39.

43. Cross L. Krankengymnastik und mehr. Torticollis-Echo 1998;1:8-13.

44. Cross L. Fehlstatik und ihre Folgen. Kursskriptum. Bückeburg: 2005.

45. Daly $P$, Preston $C B$, Evans WG. Postural response of the head to bite opening in adult males. Am J Orthod 1982;82:157-60.

46. Danner H-W. Orthopädische Einflüsse auf die Funktion des Kauorgans. In: Ahlers OM, Jakstat $\mathrm{H}$, Hrsg. Klinische Funktionsanalyse Interdisziplinäres Vorgehen mit optimierten Befundbögen. Hamburg: dentaConcept, 2001:309-48.

47. Danner H-W, Sander M. Orthopädische und physiotherapeutische Konsiliarbehandlungen bei CMD. Zahnärztl Mitt 2004;94: 72-81.

48. Danzig WN, Van Dyke AR. Physical therapy as an adjunct to temporomandibular joint therapy. J Prosth Dent 1983;49:96-9.

49. Dapprich J. Funktionstherapie in der zahnärztlichen Praxis. Berlin: Quintessenz, 2004:25-6.

50. Dapprich J, Pauly T. Kiefergelenk und Wirbelsäule. ZMK - Magazin Zahnheilkunde, Management, Kultur 2005;21:490-6.

51. Dapprich J, Pauly T. Kiefergelenk und Wirbelsäule. Die Vorbehandlung der craniomandibulären Dysfunktion. ZMK 2005;21:490-2,4,6.

52. Darling DW, Kraus S, Glasheen-Wray MB. Relationship of head posture and the rest position of the mandible. J Prosth Dent 1984;52:111-5.

53. Darlow LA, Pesco J, Greenberg MS. The relationship of posture to myofascial pain dysfunction syndrome. J Am Dent Assoc $1987 ; 114: 73-5$ 
54. Darnell MW. A proposed cronology of events for forward head posture. J Craniomandib Pract 1983;1:49-54.

55. Dart RA. The postural aspect of malocclusion. J Dent Assoc S Afr 1946;1:1-21.

56. D'Attilio M, Caputi S, Epifania E, Festa F, Tecco S. Evaluation of cervical posture of children in skeletal class I, II, and III. J Craniomandib Pract 2005;23:219-28.

57. D'Attilio M, Epifania E, Ciuffolo F, Salini V, Filippi MR, Dolci M, Festa $F$, Tecco S. Cervical lordosis angle measured on lateral cephalograms; findings in skeletal class II female subjects with and without TMD: A cross sectional study. J Craniomandib Pract 2004;22:27-44.

58. D'Attilio M, Filippi MR, Femminella B, Festa F, Tecco S. The influence of an experimentally-induced malocclusion on vertebral alignment in rats: A controlled pilot study. J Craniomandib Pract 2005;23:119-29.

59. Davies PL. Electromyographic study of superficial neck muscles in mandibular function. J Dent Res 1979;58:537-8.

60. de Almeida Rego Saboya B. The importance of the axis in the study of oromyofunctional disorders - an integrated approach. Int J Orofac Myol 1985;11:5-13.

61. de Boever JA, Steenks MH. Epidemiologie, Symptomatologie und Ätiologie der kraniomandibulären Dysfunktion. In: Steenks MH, de Wijer A, Hrsg. Kiefergelenksfehlfunktionen aus physiotherapeutischer und zahnmedizinischer Sicht - Diagnose und Therapie. Berlin: Quintessenz, 1991:35-43.

62. de Laat A, Meuleman H, Stevens A, Verbeke G. Correlation between cervical spine and temporomandibular disorders. Clin Oral Investig 1998;2:54-7.

63. de Laat A, Meulemann H, Stevens A. Relation between functional limitations of cervical spine and temporomandibular disorders. J Orofac Pain 1993;7:109.

64. de Steno C. The pathophysiology of TMJ dysfunction and related pain. In: Gelb H, ed. Clinical Management of Head, Neck and TMJ Pain and Dysfunction. Philadelphia: W. B. Saunders, 1977:1-31.

65. de Steno C. The pathophysiology of TMJ dysfunction and related pain. In: Gelb H, ed. Clinical Management of Head, Neck and TMJ Pain and Dysfunction. Philadelphia: W. B. Saunders, 1985:1-30.

66. de Wijer A. Nekklachten en temporomandibulaire dysfuncties. Ned Tijdschr Tandheelkd 1996;103:263-6.

67. de Wijer A, Steenks MH. Cervical spine evaluation for the temporomandibular disorders patient, a review. In: Friction JR, Dubner R, eds. Advances in Orofacial Pain and Temporomandibular Disorders. New York: Raven Press, 1995: 351-61.

68. de Wijer A, Steenks MH, Bosman F, Helders PJ, Faber J. Symptoms of the stomatognathic system in temporomandibular and cervical spine disorders. J Oral Rehabil 1996;23:733-41.

69. de Wijer A, Steenks MH, de Leeuw JR, Bosman F, Helders PJ. Symptoms of the cervical spine in temporomandibular and cervical spine disorders. J Oral Rehabil 1996;23:742-50.

70. Dogan S, Ertürk N. The effect of vision on craniocervical posture and its relation to craniofacial and dentoalveolar morphology. Quintessence Int 1990;21:401-6.

71. dos Santos JJ, Murakami T, Nelson SJ. Orthopedic considerations of cervical syndrome and temporomandibular disorders. Tex Dent J 1989;106:8-13.

72. Duclos P, Dumont JC. Modifications dento-maxillo-faciales provoquées chez les enfants porteurs de l'appareillage ortopédique de Milwaukee dans les scolioses vertébrales (ancien et nouveau modèle). Orthod Fr 1975;46:270-1.

73. Duyzings JAC. Kieferorthopädie und Körperhaltung. Dtsch Zahnärztl Z 1955;10:19-21.

74. Dworkin SF, LeResche L. Research diagnostic criteria for temporomandibular disorders: review, criteria, examinations and specifications, critique. J Craniomandib Disord Facial Oral Pain 1992;6: 301-55.
75. Dworkin SF, Turner JA, Wilson L, Massoth D, Whitney C, Huggins KH, Burgess J, Sommers E, Truelove E. Brief group cognitive-behavioral intervention for temporomandibular disorders. Pain 1994;59: 175-87.

76. Ehrlich R, Garlick D, Ninio M. The effect of jaw clenching on the electromyographic activities of 2 neck and 2 trunk muscles. J Orofac Pain 1999;13:115-20.

77. Erichsen H. Wirbelsäule und Kiefergelenk - intensive Wechselwirkungen. Man Med 1999;37:53.

78. Eriksson P-0, Häggman-Henrikson B, Nordh E, Zafar H. Co-ordinated mandibular and head-neck movements during rythmic jaw activities in man. J Dent Res 2000;79:1378-84.

79. Eriksson P-0, Zafar H, Nordh E. Concomitant mandibular and headneck movements during jaw opening-closing in man. J Oral Rehabil 1998;25:859-70.

80. Falck F, Fränkel C. Kopfhaltung und oraler Funktionsraum - ein kieferorthopädisches Problem. Zahn Mund Kieferheilkd 1983;71:191-7.

81. Farella M, Michelotti A, Pellegrino G, Giani U, Martina R. Interexaminer reliability and validity for diagnosis of temporomandibular disorders of visual leg measurements used in dental kinesiology. J Orofac Pain 2005;19:285-90.

82. Ferrario VF, Sforza C, Dellavia C, Tartaglia GM. Evidence of an influence of asymmetrical occlusal interferences on the activity of the sternocleidomastoid muscle. J Oral Rehabil 2003;30:34-40.

83. Ferrario VF, Sforza C, Schmitz JH, Taroni A. Occlusion and center of foot pressure variation: Is there a relationship? J Prosth Dent 1996;76:302-8.

84. Fink M, Tschernitschek H, Karst M, Stiesch-Scholz M. Asymptomatische Dysfunktion der Zervikalregion bei Patienten mit anteriorer Diskusverlagerung ohne Reposition. Dtsch Zahnärztl Z 2003;58: 625-8.

85. Fink M, Tschernitschek H, Stiesch-Scholz M. Asymptomatic cervical spine dysfunction (CSD) in patients with internal derangement of the temporomandibular joint. J Craniomandib Pract 2002;20: 192-7.

86. Fink M, Tschernitschek H, Stiesch-Scholz M, Wähling K. Kraniomandibuläres System und Wirbelsäule; Funktionelle Zusammenhänge mit der Zervikal- und Lenden-Becken-Hüft-Region. Man Med 2003;41:476-80.

87. Fink M, Tschernitschek H, Wähling K, Stiesch-Scholz M. Einfluss okklusaler Veränderungen auf die Funktion der Wirbelsäule. Zahnärztl Welt 2004;113:314-21.

88. Fink M, Wähling K, Stiesch-Scholz M, Tschernitschek H. The functional relationship between the craniomandibular system, cervical spine, and the sacroiliac joint: A preliminary investigation. J Craniomandib Pract 2003;21:202-8.

89. Forsberg C-M, Hellsing E, Linder-Aronson S, Sheikholeslam A. EMG activity in neck and masticatory muscles in relation to extension and flexion of the head. Eur J Orthod 1985;7:177-84.

90. Franks AST. Cervical spondylosis presenting as the facial pain of temporomandibular joint disorder. Ann Phys Med 1968;9:193-6.

91. Freesmeyer WB. Zahnärztliche Funktionstherapie. München: Hanser, 1993.

92. Freunthaller P. Auswirkungen der Milwaukeemiederbehandlungen am Gebiss. Zahnärztl Prax 1966;17:89-91.

93. Frumker SC, Kyle MA. The dentist's contribution to rehabilitation of cervical posture and function: orthopedic and neurological considerations in the treatment of craniomandibular disorders. Basal Facts 1985;9:105-9.

94. Fuentes Fernández RE. Klinische Untersuchung über die Zusammenhänge zwischen craniomandibulären Funktionsstörungen und Fehlhaltungen des Körpers. Inaug.-Diss., Med. Fak. Berlin: Freie Universität, 1998.

95. Fuentes Fernández RE, Freesmeyer W, Henríquez J. Influencia de la 
postura corporal en la prevalencia de las disfunciones craneomandibulares. Rev Med Chile 1999;127:1079-85.

96. Funakoshi M, Amano N. Effects of the tonic neck reflex on the jaw muscles of the rat. J Dent Res 1973;52:668-73.

97. Funakoshi M, Fujita N, Takehara S. Relations between occlusal interference and jaw muscle activities in response to changes in head position. J Dent Res 1976;55:684-90.

98. Gadotti IC, Berzin F, Biasotto-Gonzalez D. Preliminary rapport on head posture and muscle activity in subjects with class I and II. J Oral Rehabil 2005;32:794-9.

99. Gangloff P, Louis J-P, Perrin PP. Dental occlusion modifies gaze and posture stabilization in human subjects. Neurosci Lett 2000;293:2036.

100. Gelb H. A review correlating the medical-dental relationship in the cranio-mandibular syndrome. NY J Dent 1971;41:163-75.

101. Gelb H. Kraniozervikale und Kiefergelenkstörungen. In: Kraus $H$, Hrsg. Diagnose und Behandlung von Muskelschmerzen. Berlin: Quintessenz, 1989: 82-92.

102. Gelb H, Arnold GE. Syndromes of the head and neck of dental origin. AMA Arch Otolaryngol 1959;70:681-91.

103. Gelb H, Taste J. A two-year clinical dental evaluation of 200 cases of chronic headache: the craniocervical-mandibular syndrome. J Am Dent Assoc 1975;91:1230-6.

104. Gillespie B. Dental considerations of the craniosacral mechanism. J Craniomandib Pract 1985;3:380-4.

105. Göhring TN, Ahlers 0, Jakstat HA, Tioka A, Jüde HD, Toussaint R, Liebs $\mathrm{T}$, Rehder U. Kranio-mandibuläre Funktionsstörungen bei Hamburger Bauarbeitern: Erste Ergebnisse. Dtsch Zahnärztl Z 1997;52:280-2.

106. Göhring TN, Ahlers OM, Jakstat HA, Tioka A, Jüde HD, Toussaint R, Liebs T, Gawlik C, Rehder U. Interdisziplinäre Studie zu Funktionsstörungen bei Hamburger Bauarbeitern. Ein Zwischenbericht. Dtsch Zahnärztl Z 1997;52:617-9.

107. Goldstein DF, Kraus SL, Williams WB, Glasheen-Wray M. Influence of cervical posture on mandibular movement. J Prosth Dent 1984;52:421-6.

108. Gole DR. A clinical observation: a relationship of occlusal contacts to distal musculature. J Craniomandib Pract 1993;11:55-61.

109. Gonzalez HE, Manns A. Forward head posture: Its structural and functional influence on the stomatognathic system, a conceptual study. J Craniomandib Pract 1996;14:71-80.

110. Gregory TM. Temporomandibular disorder associated with sacroiliac sprain. J Manip Physiol Ther 1993;16:256-65.

111. Gresham H, Smithells PA. Cervical and mandibular posture. Dent Rec 1954;74:261-4.

112. Griegel-Morris P, Larson K, Mueller-Klaus K, Oatis CA. Incidence of common postural abnormalities in the cervical, shoulder, and thoracic regions and their association with pain in two age groups of healthy subjects. Phys Ther 1992;72:425-31.

113. Griffiths C, Thexton AJ, McGarrick JD. The effect of head position upon jaw reflexes in the rat. Arch Oral Biol 1983;28:359-61.

114. Grosse-Wienker M. Kieferdeformierungen und Bißverlagerungen bei der Behandlung von Kyphoskoliosis. Fortschr Kieferorthop 1958; 19:209-17.

115. Hackney J, Bade D, Clawson A. Relationship between forward head posture and diagnosed internal derangement of the temporomandibular joint. J Orofac Pain 1993;7:386-90.

116. Hagberg C. General musculoskeletal complaints in a group of patients with craniomandibular disorders (CMD). A case control study. Swed Dent J 1991;15:179-85.

117. Hairston LE, Blanton PL. An electromyographic study of mandibular position in response to changes in body position. J Prosth Dent 1983;49:271-5

118. Hatanaka M. Study on the effects of the change in head position and direction of movement on the mandibular border movement in the sagittal plane. J Tokyo Dent Coll Soc 1981;81:679-727.

119. Heinrich $\mathrm{S}$. The role of physical therapy in craniofacial pain disorders: An adjunct to dental pain management. J Craniomandib Pract 1991;9:71-5.

120. Hellsing E. Craniofacial Morphology Related to Body and Head Posture. Stockholm: Karolinska Medico Chirurgiska Institutet, 1987.

121. Hellsing $E$, Hagberg $C$. Changes in maximum bite force related to extension of the head. Eur J Orthod 1990;12:148-53.

122. Hellsing E, McWilliam J, Reigo T, Spangfort E. The relationship between craniofacial morphology, head posture and spinal curvature in 8, 11, and 15-year-old children. Eur J Orthod 1987;9:254-64.

123. Hellsing G. Clinical study of location and reproducibility of three mandibular positions in relation to body posture and muscle function - points of view. J Prosth Dent 1996;75:685.

124. Hibi H, Ueda M. Body posture during sleep and disc displacement in the temporomandibular joint: a pilot study. J Oral Rehabil 2005; 32:85-9.

125. Higbie EJ, Seidel-Cobb D, Taylor LF, Cummings GS. Effect of head position on vertical mandibular opening. J Orthop Sports Phys Ther 1999;29:127-30.

126. Hinz E: Beziehung von Zahn- bzw. Kieferfehlstellungen sowie Kiefergelenkstörungen zu Wirbelsäulendeformitäten, Diagnoseverfahren. Inaug.-Diss., Med. Fak. Münster: Westfälische Wilhelms-Universität, 1999.

127. Hirschfelder H, Hirschfelder U. Die Halswirbelsäule im seitlichen Fernröntgenbild aus orthopädischer Sicht. Fortschr Kieferorthop 1982;43:52-6.

128. Hirschfelder U, Hirschfelder H. Veränderungen der oberen Halswirbelsäule bei Patienten des progenen Formenkreises. Dtsch Zahnärztl Z 1982;37:692-7.

129. Hirschfelder U, Hirschfelder H. Auswirkungen der Skoliose auf den Gesichtsschädel. Fortschr Kieferorthop 1983;44:457-67.

130. Hirschfelder U, Hirschfelder H. Sagittale Kieferrelation und Wirbelsäulenhaltung: Untersuchungen zur Frage einer Abhängigkeit. Fortschr Kieferorthop 1987;48:436-48.

131. Hirschfelder U, Hirschfelder H, Schnizlein B. Veränderungen des Gesichtsschädels beim Schiefhals aus orthopädischer und kieferorthopädischer Sicht. Z Orthop 1981;119:744-5.

132. Hitchcock HP. Treatment of malocclusion associated with scoliosis. Angle Orthod 1969;39:64-8.

133. Howard CC. A preliminary report of infraocclusion of the molars and premolars produced by orthopaedic treatment of scoliosis. Int $\mathrm{J}$ Orthod 1926;12:434-7.

134. Howard CC. A second report of infraocclusion of the molars and premolars produced by orthopaedic treatment of scoliosis. Int J Orthod 1929;15:329-33.

135. Howard JT. The effects of gnathologic orthopedics on the cervical spine. Int J Orthod 1983;21:12-9.

136. Hruby RJ. The total body approach to the osteopathic management of temporomandibular joint dysfunction. J Am 0steopath Assoc 1985;85:502-10.

137. Huber N: Zusammenhänge zwischen Kieferanomalien, der Halswirbelsäulenkonfiguration und der Kopfhaltung unter Berücksichtigung von Geschlecht, Alter und kieferorthopädischer Therapie. Aachen: Rheinisch-Westfälische Technische Hochschule, 1994.

138. Huggare J. Head posture and craniofacial morphology in adults from northern Finland. Proc Finn Dent Soc 1986;82:199-208.

139. Huggare J. A cross-sectional study of head posture and craniofacial growth in children from the north of Finland. Proc Finn Dent Soc 1987;83:5-15.

140. Huggare J. Association between morphology of first cervical vertebra, head posture, and cranifacial structures. Eur J Orthod 1991;13:435-40. 
141. Huggare J. Postural disorders and dentofacial morphology. Acta Odontol Scand 1998;56:383-6.

142. Huggare J, Harkness E. Associations between head posture and dental occlusion. J Dent Res 1993;72:255.

143. Huggare J, Houghton P. Associatons between atlantoaxial and craniomandibular anatomy. Growth Dev Aging 1996;60:21-30.

144. Huggare J, Pirttiniemi P, Serlo W. Head posture and dentofacial morphology in subjects treated for scoliosis. Proc Finn Dent Soc 1991;87:151-8.

145. Huggare J, Raustia AM. Head posture and cervicovertebral and craniofacial morphology in patients with craniomandibular dysfunction. J Craniomandib Pract 1992;10:173-9.

146. Hülse M, Losert-Bruggner B. Der Einfluß der Kopfgelenke und/oder der Kiefergelenke auf die Hüftabduktion. Man Med 2002;40:97100.

147. Ingervall B, Thüer U. Cheek pressure and head posture. Angle Orthod 1988;51:47-57.

148. Jaeger I. Veränderungen des Kauorganes bei der Skoliosebehandlung mit Stützkorsett. Inaug.-Diss., Med. Fak. Köln, 1967.

149. Janda V. Some aspects of extracranial causes of facial pain. J Prosth Dent 1986;56:484-6.

150. Kainz E. Die Körperhaltung und ihr Bezug zur Occlusion. Österr Zahnärzte Z 2001;1:23.

151. Karwetzky R. Die Auswirkungen allgemein-orthopädischer Maßnahmen auf das Kauorgan. Fortschr Kieferorthop 1960;21:488-90.

152. Kaufmann RS. Case reports of TMJ repositioning to improve scoliosis and the performance by athletes. NY State Dent J 1980;46: 206-9.

153. Kawamura T. Electromyographic study on the activities of the neck muscles during various mandibular movements. J Jpn Stomatol Soc 1983;50:94-115.

154. Keil B: Über die Zusammenhänge von funktionellen Störungen im Bereich des Kauorgans, der Halswirbelsäule und Kopfschmerzen. Inaug.-Diss., Med. Fak. Köln, 1993.

155. Keil B, Keil H. Zu zahnärztlichen Funktionsstörungen mit Kopfschmerzen und funktionellen Störungen der Halswirbelsäule. Dtsch Stomatol 1991;41:249-52.

156. Khan KS, Kunz R, Kleijnen J, Antes G. Systematische Übersichten und Meta-Analysen. Berlin: Springer, 2004.

157. Kibana Y, Ishijima T, Hirai T. Occlusal support and head posture. J Oral Rehabil 2002;29:58-63.

158. Kim YK, Lee SW, Chung SC, Kho HS. Comparison of muscle activity and occlusal contacts during maximal and habitual clenching in varied chair positions. J Oral Rehabil 1997;24:237-9.

159. Kirveskari $P$, Alanen $P$, Karskela V, Kaitaniemi $P$, Holtari M, Virtanen $\mathrm{T}$, Laine M. Association of functional state of stomatognathic system with mobility of cervical spine and neck muscle tenderness. Acta Odontol Scand 1988;46:281-6.

160. Kobayashi $\mathrm{H}$. Reflex responses of sternocleidomastoid muscle induced by mechanical stimulation of upper anterior tooth and forehead. J Jpn Stomatol Soc 1990;57:385-92.

161. Kobayashi Y, Hansson TL. Auswirkungen der Okklusion auf den menschlichen Körper. Phillip J Restaur Zahnmed 1988;5:255-61.

162. Kobayashi Y, Matsumoto T, Ishigami K, Hirai T. The relationship between occlusion and the body function. J Jpn Prosthod Soc 1996;40:1-23.

163. Koeck B, Bierwirth JT. Die Veränderung der Ruheschwebe des Unterkiefers in Abhängigkeit von Schwerkraft, Kopf- und Körperhaltung. Dtsch Zahnärztl Z 1986;41:1161-5.

164. Kohno S, Matsuyama T, Medina RU, Arai Y. Functional-rhythmical coupling of head and mandibular movements. J Oral Rehabil 2001;28:161-7.

165. Kohno S, Yoshida K, Kobayashi H. Pain in the sternocloidomastoid muscle and occlusal interferences. J Oral Rehabil 1988;15:385-92.

166. Komiyama 0, Kawara M, Arai M, Asano T, Kobayashi K. Posture cor- rection as part of behavioural therapy in treatment of myofascial pain with limited opening. J Oral Rehabil 1999;26:428-35.

167. Kon II, Okushko VP, Biriukova EK, Prokushev V. [Teeth-jaw anomalies in children with scoliosis]. Ortopediia travmatologiia i protezirovanie 1968;29:59-61.

168. Kondo E, Aoba TJ. Case report of malocclusion with abnormal head posture and TMJ symptoms. Am J Orthod Dentofacial Orthop 1999;116:481-93.

169. Köneke C. Die interdisziplinäre Therapie der Craniomandibulären Dysfunktion. Berlin: Quintessenz, 2004.

170. Kopp S, Friedrichs A, Pfaff G, Langbein U. Beeinflussung des funktionellen Bewegungsraumes von Hals-, Brust- und Lendenwirbelsäule durch Aufbissbehelfe - eine Pilotstudie. Man Med 2003;41: 39-51.

171. Kopp S, Plato G. Kiefergelenk: Dysfunktionen und Schmerzphänomene aus der Sicht interdisziplinärer Diagnostik und Therapie. Kieferorthop 2001;15:55-62.

172. Kopp S, Plato G, Bumann A. Die Bedeutung der oberen Kopfgelenke bei der Ätiologie von Schmerzen im Kopf-, Hals-, Nackenbereich. Dtsch Zahnärztl Z 1989;44:966-7.

173. Korbmacher H, Eggers-Stroeder G, Koch L, Kahl-Nieke B. Correlations between anomalies of the dentition and pathologies of the locomotor system - a literature review. J Orofac Orthop 2004;65:190-203.

174. Kovero 0, Hurmerinta K, Zepa I, Huggare J, Nissinen M, Könönen M. Maximal bite force and its associations with spinal posture and craniofacial morphology in young adults. Acta Odontol Scand 2002;60:365-9.

175. Kraus M, Lilienfein W, Reinhart E, Reuther J. Das Kiefergelenk in der zahnärztlich-physiotherapeutischen Kombinationsbehandlung. Krankengymn 1998;50:1545-51.

176. Kraus SL. Cervical spine influences on the craniomandibular region. In: Kraus SL, ed. TMJ Disorders - Management of the Craniomandibular Complex. New York: Churchill Livingstone, 1988: 367-404.

177. Kraus SL. Influences of the cervical spine on the stomatognathic system. In: Donatelli R, Wooden MJ, eds. Orthopaedic Physical Therapy. New York: Curchill Livingstone, 1989: 59-70.

178. Kraus SL. Cervical spine influences on the management of TMD. In: Kraus SL, ed. Temporomandibular Disorders. New York: Churchill Livingstone, 1994: 325-412.

179. Kritsineli M, Shim YS. Malocclusion, body posture, and temporomandibular disorder in children with primary and mixed dentition. J Clin Pediatr Dent 1992;16:86-93.

180. La DC, Helton JW. Fracture of the neck of the condyle and zygoma. Report of a case. Oral Surg Oral Med Oral Pathol 1950;3:1505-8.

181. Lader E. Cervical trauma as a factor in the development of TMJ dysfunction and facial pain. J Craniomandib Pract 1983;1:86-90.

182. Lavignolle BM. Ortopédie générale et orthopédie dento-faciale. Orthod Fr 1976;47:31-67.

183. Lee $W-Y$, Okeson JP, Lindroth J. The relationship between forward head posture and temporomandibular disorders. J Orofac Pain 1995;9:161-7.

184. Lennartsson B, Friede $\mathrm{H}$. Influence on dentofacial morphology of scoliosis therapy with the original and modified Milwaukee brace. Swed Dent J 1981:5:55-64.

185. Lieb G. Auswirkungen der Skoliosebehandlung auf den Kiefer-GebissBereich bei Anwendung des Milwaukee-Korsetts. Dtsch Zahnärztl Z 1968;23:430-5.

186. Liem T. Das Kiefergelenk und die Körperhaltung. Osteo Med 2002;3:8-11.

187. Lippold C: Beziehungen zwischen physiotherapeutischen und kieferorthopädischen Befunden. Eine interdisziplinäre Studie und Patientenbefragung. Inaug.-Diss., Med. Fak. Münster: Westfälische Wilhelms-Universität, 1999.

188. Lippold C, van den Bos L. Beziehung zwischen kieferorthopädischen und orthopädischen Befunden. Man Med 2000;38:346-50. 
189. Lippold C, van den Bos L, Hohoff A, Danesh G, Ehmer U. Interdisciplinary study of orthopedic and orthodontic findings in pre-school infants. J Orofac Orthop 2003;64:330-40.

190. Logan WR. Malocclusion occuring during treatment by Milwaukee brace. Eur Orthod Soc Rep 1962;1:217-9.

191. Logan WR. Recovery of the dento-facial complex after orthopaedic treatment for scoliosis. Rep Congr Eur Orthod Soc 1968;44:197207.

192. Lotzmann U. The effect of divergent positions of maximum intercuspation on head posture. J Gnathol 1991;10:63.

193. Lotzmann U. Okklusion, Kiefergelenk und Wirbelsäule. Zahnärztl Mitt 2002;92:48-55.

194. Lotzmann U, Kobes LWR, Rudolph W, Paula MJ. Der Einfluß der Okklusion auf die Kopfhaltung während anhaltender Preßphasen. Dtsch Zahnärztl Z 1989;44:162-4.

195. Lotzmann U, Steinberg JM. The influence of occlusal stability on postural sway behavior. J Gnathol 1993;12:7-13.

196. Luedtke GL. Management of the dentition of patients under treatment for scoliosis using the Milwaukee brace. Am J Orthod 1970;57:607-14.

197. Lukanowa-Skopakowa K. Zahnkaries und Wirbelsäulenverkrümmungen bei Schülern. Fortschr Kieferorthop 1987;48:123-31.

198. Lukanowa-Skopakowa K. Zahn-Kiefer-Deformierungen und Verkrümmungen der Wirbelsäule. Fortschr Kieferorthop 1987;48:429-35.

199. Lund P, Nishiyama T, Möller E. Postural activity in the muscles of mastication with the subject upright, inclined, and supine. Scand J Dent Res 1970;78:417-24.

200. MacConkey D. The relationship of posture and dental health. Int J Orofac Myol 1991;17:8-10.

201. Makofsky HW. The effect of head posture on muscle contact position: The sliding cranium theory. J Craniomandib Pract 1989;7: 286-92.

202. Makofsky HW. The influence of forward head posture on dental occlusion. J Craniomandib Pract 2000;18:30-9.

203. Makofsky HW, August BF, Ellis JJ. A multidisciplinary approach to the evaluation and treatment of temporomandibular joint and cervical spine dysfunction. J Craniomandib Pract 1989;7:205-13.

204. Makofsky HW, Sexton TR. The effect of craniovertebral fusion on occlusion. J Craniomandib Pract 1994;12:38-46.

205. Makofsky HW, Sexton TR, Diamond DZ, Sexton MT. The effect of head posture on muscle contact position using the $t$-scan system of occlusal analysis. J Craniomandib Pract 1991;9:316-21.

206. Mannheimer JS, Rosenthal RM. Acute and chronic postural abnormalities as related to craniofacial pain and temporomandibular disorders. Dent Clin North Am 1991;35:185-208.

207. Marcotte MR. Head posture and dentofacial proportions. Angle Orthod 1981;51:208-13.

208. McLean L. The effect of postural correction on muscle activation amplitudes recorded from the cervicobrachial region. J Electromyogr Kinesiol 2005;15:527-35.

209. McLean LF, Brenman HS, Friedman MGF. Effects of changing body position on dental occlusion. J Dent Res 1973;52:1041-5.

210. Mertensmeier I, Diedrich P. Der Zusammenhang von Halswirbelsäulenstellung und Gebißanomalien. Fortschr Kieferorthop 1992;52: 26-32.

211. Michelotti A, Manzo P, Farella M, Martina R. Occlusione e postura: quali le ebvidenze di correlazione? Minerva Stomatol 1999;48: 525-34.

212. Milani RS, de Periere DD, Lapeyre L, Pourreyron L. Relationship between dental occlusion and posture. J Craniomandib Pract 2000; 18:127-34.

213. Milidonis MK, Kraus SL, Segal RL, Widmer CG. Genioglossi muscle activity in response to changes in anterior/neutral head posture. Am J Orthod Dentofacial Orthop 1993;103:39-44.
214. Minervini G, Scioli F. Riflessioni sulla postura del capo in ortognatodonzia. Arch Stomatol 1990;31:557-64.

215. Miralles R, Mendoza C, Santander H, Zuniga C, Moya H. Influence of stabilization occlusal splints on sternocleidomastoid and masseter electromyographic activity. J Craniomandib Pract 1992;10:297304.

216. Miralles R, Moya H, Ravera MJ, Santander H, Zuniga C, Carvajal R, Yazigi C. Increase of the vertical occlusal dimension by means of a removable orthodontic appliance and its effect on craniocervical relationships and position of the cervical spine in children. J Craniomandib Pract 1997;15:221-8.

217. Miralles R, Palazzi C, Ormeno G, Giannini R, Verdugo F, Valenzuela S, Santander H. Body position effects on EMG activity of sternocleidomastoid and masseter muscles in healthy subjects. J Craniomandib Pract 1998:16:90-9.

218. Mohl ND. Head posture and its role in occlusion. NY State Dent J 1976;42:17-23

219. Mohl ND. Head posture and its role in occlusion. Int J Orthod 1977;15:6-14.

220. Mohl ND. Der Einfluß der Kopfhaltung auf die Unterkieferfunktion. In: Solberg WK, Clark GT, eds. Kieferfunktion - Diagnostik und Therapie. Berlin: Quintessenz, 1985: 101-20.

221. Moro K, Yamaguchi A, Nishimura K. Influence of tooth extraction of postural stability. Shigaku 1989;77:969-82.

222. Motoyoshi M, Shimazaki T, Hosoi K, Wada M, Namura S. Stresses on the cervical column associated with vertical occlusal alteration. Eur J Orthod 2003;25:135-8.

223. Motoyoshi M, Shimazaki T, Maruyama J, Nakjima A, Namura S. Biomechanical influences on the upper vertebrae during mastication, an examination using the finite element methode. Orthod Waves 2000;59:183-90.

224. Motoyoshi M, Shimazaki T, Sugai T, Namura S. Biomechanical influences of head posture on occlusion: an experimental study using finite element analysis. Eur J Orthod 2002;24:319-26.

225. Moya H, Miralles R, Zuniga C, Carvajal R, Rocabado M, Santander H. Influence of stabilization occlusal splint on craniocervical relationships. Part I: Cephalometric analysis. J Craniomandib Pract 1994;12:47-51.

226. Mühlbach R, Rink B. Beitrag zur Häufigkeit von Gebissanomalien bei Patienten mit Adoleszentenskoliosen und Morbus Scheuermann. Beitr Orthop Traumatol 1977;24:20-5.

227. Müller-Wachendorff R. Untersuchungen über die Häufigkeit des Auftretens von Gebissanomalien in Verbindung mit Skelettdeformierungen mit besonderer Berücksichtigung der Skoliosen. Fortschr Kieferorthop 1961;22:399-408.

228. Müller-Wachendorff R. Neue Untersuchungen über Dysgnathien bei Haltungsfehlern. Fortschr Kieferorthop 1966;27:487-95.

229. Munhoz WC, Marques AP, de Siqueira JTT. Radiographic evaluation of cervical spine of subjects with temporomandibular joint internal disorder. Braz Oral Res 2004;18:283-9.

230. Munhoz WC, Marques AP, de Siqueira JTT. Evaluation of body posture in individuals with internal temporomandibular joint derangement. J Craniomandib Pract 2005:23:269-77.

231. Nagasuna T, Tanaka M, Kawazoe T, Morikawa M, Matsumoto S. Postural synergy of sternocleidomastoid muscle for control of head position during ballistic voluntary jaw movements. J Jpn Prosthod Soc 1993:37:1232-7.

232. Neuhuber W. M. longissimus als Vermittler zwischen kraniozervikalem Übergang und Becken - Eine Hypothese. Man Med 2005;43: 395-9.

233. Nicolakis P, Nicolakis M, Piehslinger E, Ebenbichler G, Vachuda M, Kirtley C, Fialka-Moser V. Relationship between craniomandibular disorders and poor posture. J Craniomandib Pract 2000;18: $106-12$. 
234. Nicolakis P, Piehslinger E, Nicolakis M, Vachuda M, Fialka-Moser V. Zusammenhänge zwischen Haltungsasymmetrien und dem Ruhetonus des M. masseter. Dtsch Zahnärztl Z 1998;53:608-12.

235. Nilsson M, Huggare J, Hellsing E. Associations between spinal morphology and dental occlusion. Acta Univ Oulu D 1998.

236. Nobili A, Adversi R. Relationship between posture and occlusion: a clinical and experimental investigation. J Craniomandib Pract 1996;14:274-85.

237. Nöcker K. Zähne und Halswirbelsäule - Gibt es Verbindungen zwischen Halswirbelsäulenerkrankungen, dem Kauorgan und mögliche Mitursachen des Tinnitusgeschehens? - Eine rein anatomische Betrachtung. Tinnitus-Forum 2005;2:13-4.

238. Nordh E, Eriksson PO, Zafar H, Al-Falahe N. Concomitant mandibular and head-neck movements during natural jaw opening-closing indicates parallel neuromuscular activation of jaw and head-neck-systems. Eur J Neurosci Supp 1993;6:279.

239. Obst 0. Die Grenzen der Literaturdatenbanken. CardioNews 2001;4:22-4.

240. Olmos SR, Kritz-Silverstein D, Halligan W, Silverstein ST. The effect of condyle fossa relationships on head posture. J Craniomandib Pract 2005;23:48-52.

241. Omae T, Inoue $S$, Saito 0, Ishii $H$, Ishigaki $S$, Okuda T, Nakamura $T$, Akanishi M, Maruyama T. Electromyographic study on the effects of head position to head and neck muscles. J Jpn Prosthod Soc 1989;33:352-8.

242. Ormeno G, Miralles R, Loyola R, Valenzuela S, Santander H, Palazzi C, Villanueva P. Body position effects on EMG activity of the temporal and suprahyoid muscles in healthy subjects and in patients with myogenic cranio-cervical-mandibular dysfunction. J Craniomandib Pract 1999;17:132-42.

243. Ormeno G, Miralles R, Santander H, Casassus R, Ferrer P, Palazzi C, Moya $\mathrm{H}$. Body position effects on sternocleidomastoid and masseter EMG pattern activity in patients undergoing occlusal splint therapy. J Craniomandib Pract 1997;15:300-9.

244. Palazzi C, Miralles R, Miranda C, Valenzuela S, Casassus R, Santander $\mathrm{H}$, Ormeno G. Effects of two types of pillows on bilateral sternocleidomastoid EMG activity in healthy subjects and in patients with myogenic cranio-cervical-mandibular dysfunction. J Craniomandib Pract 1999;17:202-12.

245. Palazzi C, Miralles R, Soto MA, Santander H, Zuniga C, Moya H. Body position effects on EMG activity of sternocleidomastoid and masseter muscles in patients with myogenic cranio-cervical-mandibular dysfunction. J Craniomandib Pract 1996;14:200-9.

246. Paphalmy Z, Kallay M, Tomory I. Scoliosisos gyermekek kezelése közben fellépö fogsordeformitások megelözése [0cclusal deformities in children treated for scoliosis]. Fogorv Sz 1975;68:374-6.

247. Pavsic J. Pogostnost disgnatij pri otrocih s skoliozami v sr sloveniji [0ccurrence of dysgnathies children with scoliosis]. Zobozdravstveni vestnik 1974;29:29-37.

248. Pavsic J. Untersuchungen zum Einfluß kieferorthopädischer Maßnahmen auf das Wachstum des Unterkiefers bei Skoliosepatienten während der Behandlung mit dem Milwaukee-Mieder. Stomatol DDR 1983:33:676-82.

249. Pavsic J, Bizjak F. Orofaziale Anomalien bei der Behandlung der Skoliose mit dem Milwaukee-Korsett. Österr Z Stomatol 1972;69: 337-42.

250. Pavsic J, Bizjak F, Antolic I, Farcnik SF. Skolioze in maksilo-facialne anomalije [Scoliosis and maxillo-facial anomalies]. Zobozdravstveni vestnik 1970;25:223-34.

251. Pecina M, Lulic-Dukic 0, Pecina-Hrncevic A. Hereditary orthodontic anomalies and idiopathic scoliosis. Int Orthop 1991;15:57-9.

252. Peres AC, Peres RL. Kiefer und Körperhaltung - wie und warum Haltung und Bewegung auch durch Zähne und Bisslage beeinflusst werden. GZM 2004;9:18-22.
253. Perinetti G. Dental occlusion and body posture: No detectable correlation. Gait posture 2005;3:364-71.

254. Persky SL, Johnston LE. An evaluation of dentofacial changes accompanying scoliosis therapy with a modified Milwaukee brace. Am J Orthod 1974;65:364-71.

255. Phillips C, Snow MD, Turvey TA, Proffit WR. The effect of orthognatic surgery on head posture. Eur J Orthod 1991;13:397-403.

256. Pradham NS, White GE, Metha N, Forgione A. Mandibular deviations in TMD and non-TMD groups related to eye dominance and head posture. J Clin Pediatr Dent 2001;25:147-55.

257. Prager A. Untersuchungen über die Zusammenhänge zwischen Deformitäten der Wirbelsäule und Kieferanomalien. Inaug.-Diss., Med. Fak. Mainz: Johannes Gutenberg-Universität, 1979.

258. Prager A. Vergleichende Untersuchungen über die Häufigkeit von Zahnstellungs- und Kieferanomalien bei Patienten mit Deformitäten der Wirbelsäule. Fortschr Kieferorthop 1980;41:163-8.

259. Pruzansky S. The control of the posture of the mandible during rotating of the head. J Dent Res 1955;34:720.

260. Ricken C. Allgemeiner Befund- und Dokumentationsbogen bei CMD für Physiotherapeuten. In: Stelzenmüller W, Wiesner J, Hrsg. Therapie von Kiefergelenkschmerzen. Ein Behandlungskonzept für Zahnärzte, Kieferorthopäden und Physiotherapeuten. Stuttgart: Thieme, 2004:64-90.

261. Ridder P-H. Kieferfunktionsstörungen und Zahnfehlstellungen mit ihren Auswirkungen auf die Körperperipherie. Man Med 1998;36: 194-203.

262. Rietschel-Große-Büning D-J. Zahnanomalien bei Skoliosepatienten. Inaug.-Diss., Med. Fak. Düsseldorf: Heinrich-Heine-Universität, 1988.

263. Robinson MJ. The influence of head position on temporomandibular joint dysfunction. J Prosth Dent 1966;16:169-72.

264. Robson FC. The clinical evaluation of posture: Relationship of the jaw and posture. J Craniomandib Pract 2001;19:144.

265. Rocabado M. Biomechanical relationship of the cranial, cervical and hyoid regions. J Craniomandib Pract 1983;1:62-.

266. Rocabado M. Diagnosis and treatment of abnormal craniocervical and craniomandibular mechanics. In: Solberg WK, Clark GT, eds. Abnormal Jaw Mechanics: Diagnosis and Treatment. Chicago: Quintessenz, 1984:141-9.

267. Rocabado M. Diagnose und Behandlung einer abnormen kraniozervikalen und kraniomandibulären Mechanik. In: Solberg WK, Clark GT, Hrsg. Kieferfunktion - Diagnose und Therapie. Berlin: Quintessenz, 1985:145-64.

268. Rocabado M, Johnston BE, Blakney MG. Physical therapy and dentistry: an overview. J Craniomandib Pract 1983;1:46-9.

269. Rocabado M, Tapia V. Radiographic study of the craniocervical relation in patients under orthodontic treatment and the incidence of related symptoms. J Craniomandib Pract 1987;5:36-42.

270. Rodrigues MJ, Lotzmann U, Rudolf W. Influence of occlusion on head posture during periods of continuous intermaxillary pressure. Stoma 1990;2:57-8, 61-4.

271. Root GR, Kraus SL, Razook SJ, Samson GS. Effect of an intraoral splint on head and neck posture. J Prosth Dent 1987;58:90-5.

272. Salonen MAM, Raustia AM, Huggare J. Head and cervical spine postures in complete denture wearers. J Craniomandib Pract 1993;11:30-3.

273. Salonen MAM, Raustia AM, Huggare JA. Changes in head and cervical-spine posture and EMG activities of masticatory muscles following treatment with complete upper and partial lower denture. J Craniomandib Pract 1994;12:222-6.

274. Sandikcioglu M, Skov S, Solow B. Atlas morphology in relation to craniofacial morphology and head posture. Eur J Orthod 1994;16: 96-103.

275. Santander H, Miralles R, Jimenez A, Zuniga C, Rocabado M, Moya H. Influence of stabilization occlusal splint on craniocervical relation- 
ships. Part II: Electromyographic analysis. J Craniomandib Pract 1994;12:227-33.

276. Santander H, Miralles R, Perez J, Valenzuela S, Ravera MJ, Ormeno $G$, Villegas R. Effects of head and neck inclination on bilateral sternocleidomastoid EMG activity in healthy subjects and in patients with myogenic cranio-cervical-mandibular dysfunction. J Craniomandib Pract 2000;18:181-91.

277. Santi G, Ferrando C, Beccario L. Gnathodontic changes in patients under treatment for scoliosis. Stomatologica 1967;11:101-21.

278. Santi G, Ferrando C, Beccario L. On the possibility of an orthodontic treatment for maxillofacial deformity due to treatment for scoliosis. Stomatologica 1968;12:134-53.

279. Sato T, Hannak W, Freesmeyer WB, Ishikawa T. Untersuchung über den Einfluß von Okklusionsänderungen auf die Körperhaltung. Zahnärztl Welt 2000;109:147-53.

280. Savjani D, Wertheim D, Edler R. Change in cranio-cervical angulation following orthognathic surgery. Eur J Orthod 2005;27:268-73.

281. Schmidt L. Worte sind Waffen. Aphorismen zur Gegenwart. 4. Aufl. Frankfurt am Main: Frankfurter Allgemeine Buch, 1999:97.

282. Schmuth GPF. Probleme der Verankerung von Biß-Stützapparaten bei Skoliosepatienten. Fortschr Kieferorthop 1966;27:429-32.

283. Schoo K, Becker Y. Arbeitsskript zum Einführungskurs Kiefergelenk. (Kursmanuskript zum Thema Regenerative Wirbelsäulengymnastik nach Cross) Bückeburg: 2005.

284. Schupp W. Kraniomandibuläre Dysfunktionen und deren Folgen eine Literaturübersicht. Man Med 2005;43:29-33.

285. Schwarz AM. Kopfhaltung und Kiefer. Z Stomatol 1926;24: 669-744.

286. Schwarz AM. Positions of the head and malrelations of the jaws. Int J Orthod Oral Surg Radiol 1928;14:56-8.

287. Seedorf H, Toussaint R, Jakstat HA, Ahlers 0, Liebs T, Göhring T, Jüde HD. Zusammenhänge zwischen Wirbelsäulen-Funktion, Beckentiefstand und kraniomandibulärer Dysfunktion. Dtsch Zahnärztl Z 1999;54:700-3.

288. Serviere F. L'examen postural en occlusodontie quotidienne. Cah Prothese 1989;65:37-42.

289. Shiau $Y-Y$, Chai H-M. Body posture and hand strength of patients with temporomandibular disorders. J Craniomandib Pract 1990;8:244-51.

290. Shimazaki T, Motoyoshi M, Hosoi K, Namura S. The effect of occlusal alteration and masticatory imbalance on the cervical spine. Eur J Orthod 2003;25:457-63.

291. Slavicek R. Die Haltung. Zur Physiologie und Pathophysiologie der Körper- und Kopfhaltung beim modernen Menschen. In: Slavicek R, Hrsg. Das Kauorgan: Funktionen und Dysfunktionen. Klosterneuburg: Gamma Medizinisch-wissenschaftliche Fortbildungsgesellschaft, 2000: 265-70.

292. Solow B, Sandham A. Cranio-cervical posture: a factor in the development and function of the dentofacial structures. Eur $\mathrm{J}$ Orthod 2002;24:447-56.

293. Solow B, Siersbaek-Nielsen S. Growth changes in head posture related to craniofacial developement. Am J Orthod 1986;89:132-40.

294. Solow B, Siersbaek-Nielsen S. Cervical and craniocervical posture as predictors of craniofacial growth. Am J Orthod Dentofacial Orthop 1992;101:449-58.

295. Solow B, Sonnesen L. Head posture and malocclusions. Eur J Orthod 1998;20:685-93.

296. Solow B, Tallgren A. Craniocervical posture in relation to skeletal and dentoalveolar morphology. Eur Orthod Soc Rep 1975;1:111-5.

297. Solow B, Tallgren A. Dentoalveolar morphology in relation to craniocervical posture. Angle Orthod 1977;47:157-64.

298. Sonnesen L, Bakke M. Molar bite force in relation to occlusion, craniofacial dimensions, and head posture in pre-orthodontic children. Eur J Orthod 2005;27:58-63.
299. Sonnesen L, Bakke M, Solow B. Temporomandibular disorders in relation to craniofacial dimensions, head posture and bite force in children selected for orthodontic treatment. Eur J Orthod 2001; 23:179-92.

300. Southard TE, Southard KA, Tolley EA. Variation of approximal tooth contact tightness with postural change. J Dent Res 1990;69: 1776-9.

301. Steinmetz A, Ridder PH, Reichelt A. Kraniomandibuläre Dysfunktionen und deren Einfluss auf die Schulter-Nacken-Muskulatur bei Geigern. Man Med 2005;43:249-56.

302. Stelzenmüller W. Allgemeiner Befund- und Dokumentationsbogen bei CMD für Physiotherapeuten. In: Stelzenmüller W, Wiesner J, Hrsg. Therapie von Kiefergelenkschmerzen. Ein Behandlungskonzept für Zahnärzte, Kieferorthopäden und Physiotherapeuten. Stuttgart: Thieme, 2004:117-34.

303. Stelzenmüller W. Allgemeines zur physiotherapeutischen Behandlung von Kiefergelenkpatienten. In: Stelzenmüller W, Wiesner J, Hrsg. Therapie von Kiefergelenkschmerzen. Ein Behandlungskonzept für Zahnärzte, Kieferorthopäden und Physiotherapeuten. Stuttgart: Thieme, 2004:109-16.

304. Stelzenmüller W, Wiesner J. Therapie von Kiefergelenkschmerzen. Stuttgart: Thieme, 2004

305. Stiesch-Scholz M, Fink M, Tschernitschek H. Ätiologische Aspekte bei Funktionserkrankungen der Halswirbelsäule und des kraniomandibulären Systems. Zahnärztl Welt 2001;110:721-6.

306. Stiesch-Scholz M, Fink M, Tschernitschek H. Comorbidity of internal derangement of the temporomandibular joint and silent dysfunction of the cervical spine. J Oral Rehabil 2003;30:386-91.

307. Stiesch-Scholz M, Tschernitschek H, Fink M. Wechselwirkungen zwischen dem temporomandibulären und kraniozervikalen System bei Funktionserkrankungen des Kauorgans. Phys Med Rehab Kuror 2002;12:83-8.

308. Stilwell FS. The correlation of malocclusion and scoliosis to posture; or posture and its effect upon teeth and spine. Dent Cosmos 1927;69:154-63.

309. Stöckli P, Hotz R, Gisler G, Scheier H. Auswirkungen der Skoliosebehandlung mit Extensionskorsetten auf den Kiefer-/Gesichts-Bereich. Schweiz Monatsschr Zahnheilkd 1967;77:1029-57.

310. Stoll V. The importance of correct jaw relations in cervico-oralfacial orthopaedia. Basal Facts 1977;2:34-9.

311. Straus SE, Richardson WS, Glasziou P, Haynes RB. Evidence-Based Medicine. How to Practice and Teach EBM. 3rd ed. Edinburgh: Churchill Livingstone, 2005.

312. Stute W. Sakrokraniomandibuläre Integrationsstörungen - StuteCross-Syndrom. In: Becker W, Hrsg. Ganzheitliche Zahnheilkunde in der Praxis. Balingen: Spitta, 1996:1-3.

313. Suzuki S, Matsubara N, Hisano M, Soma K. Investigation of a cervical muscle mechanism during jaw movement using a prototype head-jaw-neck model. J Med Dent Sci 2003;50:285-90.

314. Takigawa T, Matsuoka S, Iida J, Soma K. Jaw position, head position, body posture: development of an integrated system of examination, Part I. J Jpn Stomatol Soc 1995;62:441-50.

315. Tallgren A, Lang BR, Walker GF, Ash MM. Changes in jaw relations, hyoid position, and head posture in complete denture wearers. J Prosth Dent 1983;50:148-56.

316. Tallgren A, Solow B. Long-term changes in hyoid bone position and craniocervical posture in complete denture wearers. J Dent Res 1981;60:473.

317. Tani G. Le disgnazie in rapporto con I paramorfismi della colonna vertebrale. Riv Ital Stomatol 1965;20:71-82.

318. Tecco S, Farronato G, Salini V, Di Meo S, Filippi MR, Festa F, D`Attilio $M$. Evaluation of cervical spine posture after functional therapy with FR-2: A longitudinal study. J Craniomandib Pract 2005;23:53-66.

319. Tecco S, Festa F, Tete S, Longhi V, D' Attilio M. Changes in head 
posture after rapid maxillary expansion in mouth-breathing girls: a controlled study. Angle Orthod 2005;75:171-6.

320. Theron W, Slabbert JCG, Cleaton-Jones PE, Fatti PL. The effect of complete dentures on head posture. J Prosth Dent 1989;62:181-4.

321. Thompson JR, Brodie AG. Factors in the position of the mandible. J Am Dent Assoc 1942;29:925-41.

322. Tingey EM, Buschang PH, Throckmorton GS. Mandibular rest position: a reliable position influenced by head support and body posture. Am J Orthod Dentofacial Orthop 2001;120:614-22.

323. Travell J. Temporomandibular joint pain referred from muscles of the head and neck. J Prosth Dent 1960;10:745-63.

324. Tripodakis AP, Smulow JB, Mehta NR, Clark RE. Clinical study of location and reproducibility of three mandibular positions in relation to body posture and muscle function. J Prosth Dent 1995;73:190-8.

325. Tschernitschek H, Schliephake H, Fink M. Kraniomandibuläre Dysfunktion und Halswirbelsäulensymptomatik - wann gibt es Zusammenhänge? Dtsch Zahnärztl Z 2001;56:270-2.

326. Türp JC. Evidenzbasierte Zahnmedizin. Inf Orthod Kieferorthop 2004;36:135-41.

327. Türp JC, Schulte JM, Antes G. Nearly half of dental randomized controlled trials published in German are not included in Medline. Eur J Oral Sci 2002;110:405-11.

328. Urbanowicz M. Alteration of vertical dimension and its effect on head and neck posture. J Craniomandib Pract 1991;9:174-9.

329. Usumez A, Usumez S, Orhan M. Effect of complete dentures on dynamic measurement of changing head position: A pilot study. J Prosth Dent 2003;90:394-400.

330. v. Heymann W. Craniomandibuläre Dysfunktion und Wirbelsäule Aspekte der Wechselwirkungen. Modell einer kybernetischen Integration. In: Köneke C, Hrsg. Die interdisziplinäre Therapie der Craniomandibulären Dysfunktion. Berlin: Quintessenz, 2005:95-114.

331. Valentino B, Aldi B, Melito F, Valentino T. An EMG study on TMJ disorders. Bull Group Int Rech Sci Stomatol Odontol 2002;44: 14-8.

332. Valentino B, Fabozzo A, Melito F. The functional relationship between the occlusal plane and the plantar arches. An EMG study. Surg Radiol Anat 1991;13:171-4.

333. Valentino B, Melito F. Functional relationships between the muscles of mastication and the muscles of the leg. An electromyographic study. Surg Radiol Anat 1991;13:33-7.

334. Valentino B, Melito F, Aldi B, Valentino T. Correlation between interdental occlusal plane and plantar arches. An EMG study. Bull Group Int Rech Sci Stomatol Odontol 2002;44:10-3.

335. Valenzuela S, Miralles R, Ravera MJ, Zuniga C, Santander H, Ferrer M, Nakouzi J. Does head posture have a significant effect on the hyoid bone position and sternocleidomastoid electromyographic activity in young adults? J Craniomandib Pract 2005;23:204-11.

336. Vernon LF, Ehrenfeld DC. Treatment of temporomandibular joint syndrome for relief of cervical spine pain. J Manip Physiol Ther 1982;5:79-81.

337. Vig PS, Orth D, Rink JF, Showfety KJ. Adaption of head posture in response to relocating the center of mass: a pilot study. Am J Orthod 1983;83:138-42.

338. Vig PS, Showfety KJ, Phillips C. Experimental manipulation of head posture. Am J Orthod 1980;77:258-68.

339. Visscher CM, de Boer W, Lobbezoo F, Habets LL, Naeije M. Is there a relationship between head posture and craniomandibular pain? J Oral Rehabil 2002;29:1030-6.

340. Visscher CM, Huddlestone Slater JJ, Lobbezoo F, Naeije M. Kinematics of the human mandible for different head postures. J Oral Rehabil 2000;27:299-305.

341. Visscher CM, Lobbezoo F, de Boer W, van der Zaag J, Naeije M. Prevalence of cervical spinal pain in craniomandibular pain patients. Eur J Oral Sci 2001;109:76-80.
342. von Heymann W. Craniomandibuläre Dysfunktion und Wirbelsäule Aspekte einer Wechselbeziehung. Modell einer kybernetischen Integration. In: Köneke C, Hrsg. Die interdisziplinäre Therapie der Craniomandibulären Dysfunktion. Berlin: Quintessenz, 2005:95-114.

343. von Treuenfels H. Die Relation von Atlasposition bei prognather und progener Kieferanomalie. Fortschr Kieferorthop 1981;42:482-91.

344. von Treuenfels H. Dysgnathien, Haltungsfehler und Deformitäten der Wirbelsäule. Erster Teil. Ihre Bedeutung für die Funktionskieferorthopädie. Zahnarzt 1984;28:525-31.

345. von Treuenfels H. Dysgnathien, Haltungsfehler und Deformitäten der Wirbelsäule. Zweiter Teil. Zahnarzt 1984;28:591-604.

346. von Treuenfels H. Kopfhaltung, Atlasposition und Atemfunktion beim offenen Biß. Fortschr Kieferorthop 1984;45:111-21.

347. von Treuenfels H. Über die Relation von Dysgnathien, Haltungsfehlern und Deformitäten der Wirbelsäule. Dtsch Z Biol Zahnmed 1986;2:9-15 und 58-63.

348. von Treuenfels H. Das Gnatho-Vertebral-Syndrom. Erfahrungsheilkunde 1989;11:805-18.

349. von Treuenfels H, von Torklus D. Die Relation von Atlasposition, prognather und progener Kieferanomalie. Z Orthop 1983;121: 657-64.

350. Wachsmann K. Über den Zusammenhang der Gebißanomalien mit Krümmungen der Wirbelsäule und schlaffer Körperhaltung. Fortschr Kieferorthop 1960;21:449-53.

351. Wallisch W. Kopfhaltung und Kiefer. Z Stomatol 1926;8:60-1.

352. Wander R. Störfeld Kiefergelenk - Wirkung auf den Gesamtorganismus. Dtsch Z Akup 2004;47:28-33.

353. Wenzel A, Williams S, Ritzau M. Changes in head posture and nasopharyngeal airway following surgical correction of mandibular prognathism. Eur J Orthod 1989;11:37-42.

354. Wenzel A, Williams S, Ritzau M. Relationships of changes in craniofacial morphology, head posture, and nasopharyngeal airway size following mandibular osteotomy. Am J Orthod Dentofacial Orthop 1989;96:138-43.

355. Winkelmann C, Schreiber TU, Weih C, Harrison PR. Ansätze zur Physiotherapie bei kraniomandibulären Dysfunktionen. Krankengymn 1999;51:2042-54.

356. Winnberg A, Pancherz H. Head posture and masticatory muscle function. An EMG investigation. Eur J Orthod 1983;5:209-17.

357. Winnberg A, Pancherz H, Westesson P-L. Head posture and hyomandibular function in man. Am J Orthod Dentofacial Orthop 1988;94:393-404.

358. Woda A, Pionchon P, Palla S. Regulation of mandibular postures: mechanisms and clinical implications. Crit Rev Oral Biol Med 2001;12:166-78.

359. Wolf U, Sondermeier U, Käuser G, Lotzmann U, Wilke A. Der Einfluß der manipulativen Behandlung der Halswirbelsäule auf die kraniomandibuläre Relation. Man Ther 2000;4:104-11.

360. Wright EF, Domenech MA, Fischer JR. Usefulness of posture training for patients with temporomandibular disorders. J Am Dent Assoc 2000;131:202-10.

361. Wright EF, Schiffman EL. Treatment alternatives for patients with masticatory myofascial pain. J Am Dent Assoc 1995;126:1030-9.

362. Wright SM. The effect of body posture on the preferred vertical dimension of occlusion. J Oral Rehabil 1984;11:467-76.

363. Xie QF, Chen L, Feng HL, Huang DP. The study of natural head posture in edentulous patients before and after oral rehabilitation. Chinese J Stomatol 2003;38:35-8.

364. Yamabe Y, Torisu T, Yoshimatsu T, Hashimoto N, Fujii H. Observation of head mobility during the jaw open-close movement. J Jpn Prosthodont Soc 1997;41:463-7.

365. Yamabe Y, Yamashita R, Fujii H. Head, neck and trunk movements accompanying jaw tapping. J Oral Rehabil 1999;26:900-5.

366. Yamada R, Ogawa T, Koyano K. The effect of head posture on direc- 
tion and stability of mandibular closing movement. J Oral Rehabil 1999;26:511-20.

367. Yamaguchi H, Sueishi K. Malocclusion associated with abnormal posture. Bull Tokyo Dent Coll 2003;44:43-54.

368. Yoshida K. Electromyographical analysis of function of sternocleidomastoid muscle during occlusal function. Kokubyo Gakkai Zasshi 1988;55:53-70.

369. Yoshimatsu T, Namikoshi T, Koyama Z, Suga K, Fujii H. Changes of muscle activities in neck and shoulder region during sustained isometric contractions on jaw muscles. J Jpn Prosthod Soc 1989; 33:1044-9.

370. Yoshino G, Higashi K, Nakamura T. Changes in head position due to occlusal supporting zone loss during clenching. J Craniomandib Pract 2003;21:89-98.

371. Yoshino G, Higashi K, Nakamura T. Changes in weight distribution at the feet due to occlusal supporting zone loss during clenching. J Craniomandib Pract 2003;21:271-8.

372. Zafar H. Integrated jaw and neck function in man. Studies of mandibular and head neck movements during jaw opening-closing tasks. Swed Dent J 2000;143:1-41.

373. Zafar H, Eriksson PO, Nordh E, Al-Falahe N. Coordinated human jaw and head-neck movements during natural jaw opening-closing: reproducible movement patterns indicate linked motor control. In: Taylor A, Gladden MH, Durbaba R, eds. Alpha and Gamma Motor Systems. New York: Plenum Press, 1995:502-4.

374. Zafar H, Nordh E, Eriksson PO. Temporal coordination between mandibular and head-neck movements during jaw opening-closing tasks in man. Arch Oral Biol 2000;45:675-82.

375. Zafar H, Nordh E, Eriksson PO. Spatiotemporal consistency of human mandibular and head-neck movement trajectories during jaw opening-closing tasks. Exp Brain Res 2002;146:70-6.
376. Zang EA. The effect of the occlusal splint in the biomechanics on the cranium, cervical spine, mandible and the hyoid region. Orthod Rev 1988;2:15-21.

377. Zepa I, Hurmerinta K, Kovero 0, Nissinen M, Könönen M, Huggare J. Trunk asymmetry and facial symmetry in young adults. Acta Odontol Scand 2003;61:149-53.

378. Zonnenberg AJJ, Van Maanen CJ, Oostendorp RAB, Elvers HJW. Body posture photographs as a diagnostic aid for musculoskeletal disorders related to temporomandibular disorders (TMD). J Craniomandib Pract 1996;14:225-32.

379. Zuniga C, Miralles R, Mena B, Montt R, Moran D, Santander H, Moya $H$. Influence of variation in jaw posture on sternocleidomastoid and trapezius electromyographic activity. J Craniomandib Pract 1995;13:157-62.

\section{Correspondence Address}

Prof. Dr. Jens C. Türp

Klinik für Rekonstruktive Zahnmedizin und Myoarthropathien Universitätskliniken für Zahnmedizin

Hebelstr. 3

4056 Basel

Switzerland

Tel. (+41/61) 26726-36, Fax -60

e-mail: jens.tuerp@unibas.ch 